\section{SAAAA \\ JOURNAL}

Open Access

Journal of Archaeology and Fine Arts in Southeast

Asia

Published by the SEAMEO Regional Centre for Archaeology and Fine Arts (SPAFA)

\title{
31 Days of Borneo
}

Adeline Chai Hsia Wee

Sibu, Malaysia

alywolf.art@gmail.com

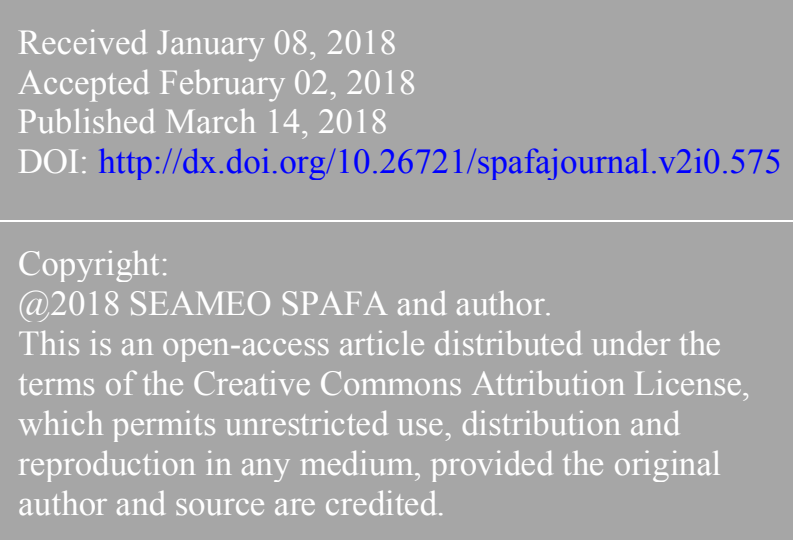

\begin{abstract}
Borneo is the world's third largest island, and is shared between Malaysia (Sabah and Sarawak), Brunei and Indonesia (Kalimantan). One thing which stands out about the island is its incredible biological and ethnocultural diversity. It also has a long history of human occupation, dating back to at least 40000 years ago. As such it has been, and continues to be, a place of archaeological, anthropological and scientific interest. This photo essay attempts in thirty-one images to explore some of this diversity and offer a very brief insight into Borneo's unique heritage.
\end{abstract}

Editor's note: This series of illustrations was discovered on Instagram and were valuable both as a collection of illustrations, and also because their subject matter shed some light on the various and diverse cultures of Borneo.

Keywords: Borneo, illustration, photo essay

31 Days of Borneo was an art initiative I undertook over winter break in 2017. Set up as an Instagram art challenge, the end goal was to upload 31 illustrations relating to Borneo, one for each day, by the end of December. Its underlying aims are more reflective than artistic, and each illustration involved either looking up something I had never seen or heard of before, or alternatively, trying to find out a bit more about the things which I had. 
One problem I faced was being spoilt for choice. Borneo's biodiversity is equalled by its cultural diversity, and it is impossible to fully represent either in just a month's time. The result was a mixed bag of archaeology, cultural arts and natural history, but having lived in Sarawak for the past 20 years the series ended up being heavily centred on the region. Many of the objects were referenced from those in museum collections, most notably that of the Sarawak Museum and the Sibu Cultural Heritage Museum where I have worked, while some creative liberties were taken with others.

Working on this series has given me a greater understanding and appreciation of the complex mix of culture, life and history that forms Borneo as it stands today. It is my intention to continue exploring this complexity, with a broader focus on the island as a whole.

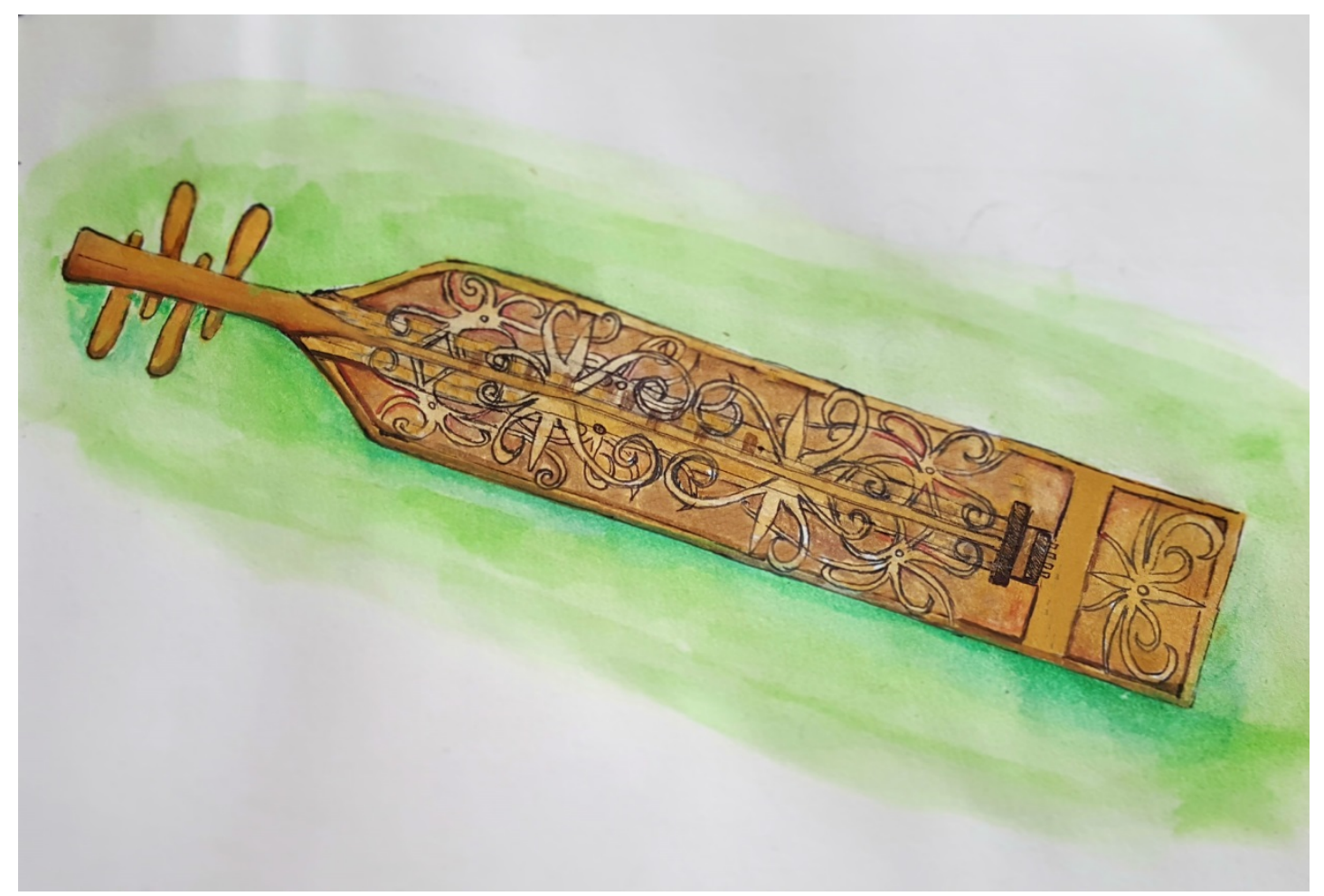

The sape is a traditional stringed instrument of the Orang Ulu in Sarawak. It is carved from a single bole of wood and is often compared to a lute. 


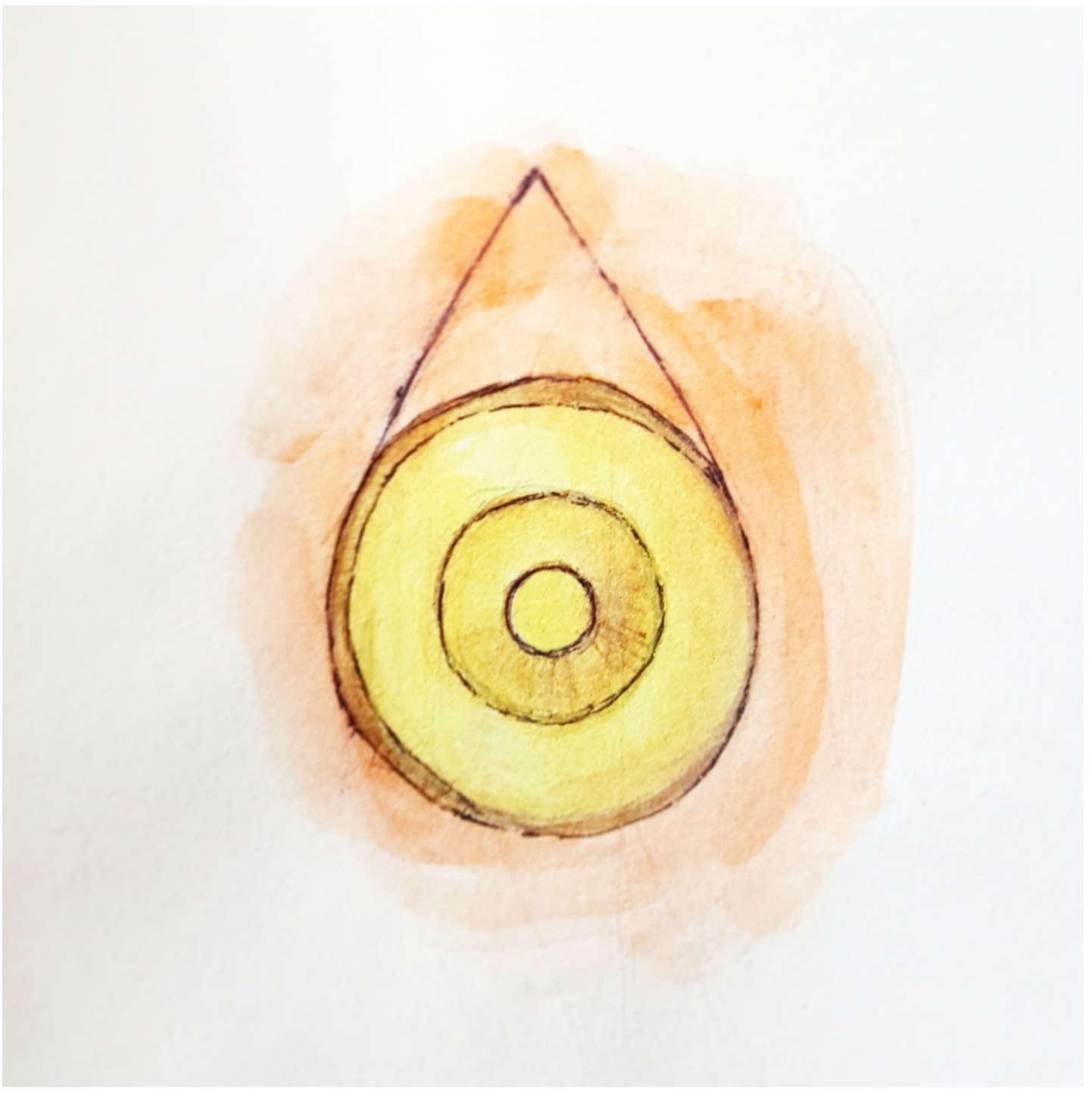

A tawak is a big, knobbed hanging brass gong, often suspended from a wooden frame. It typically forms part of a larger musical ensemble, and is relatively widespread throughout Borneo. 


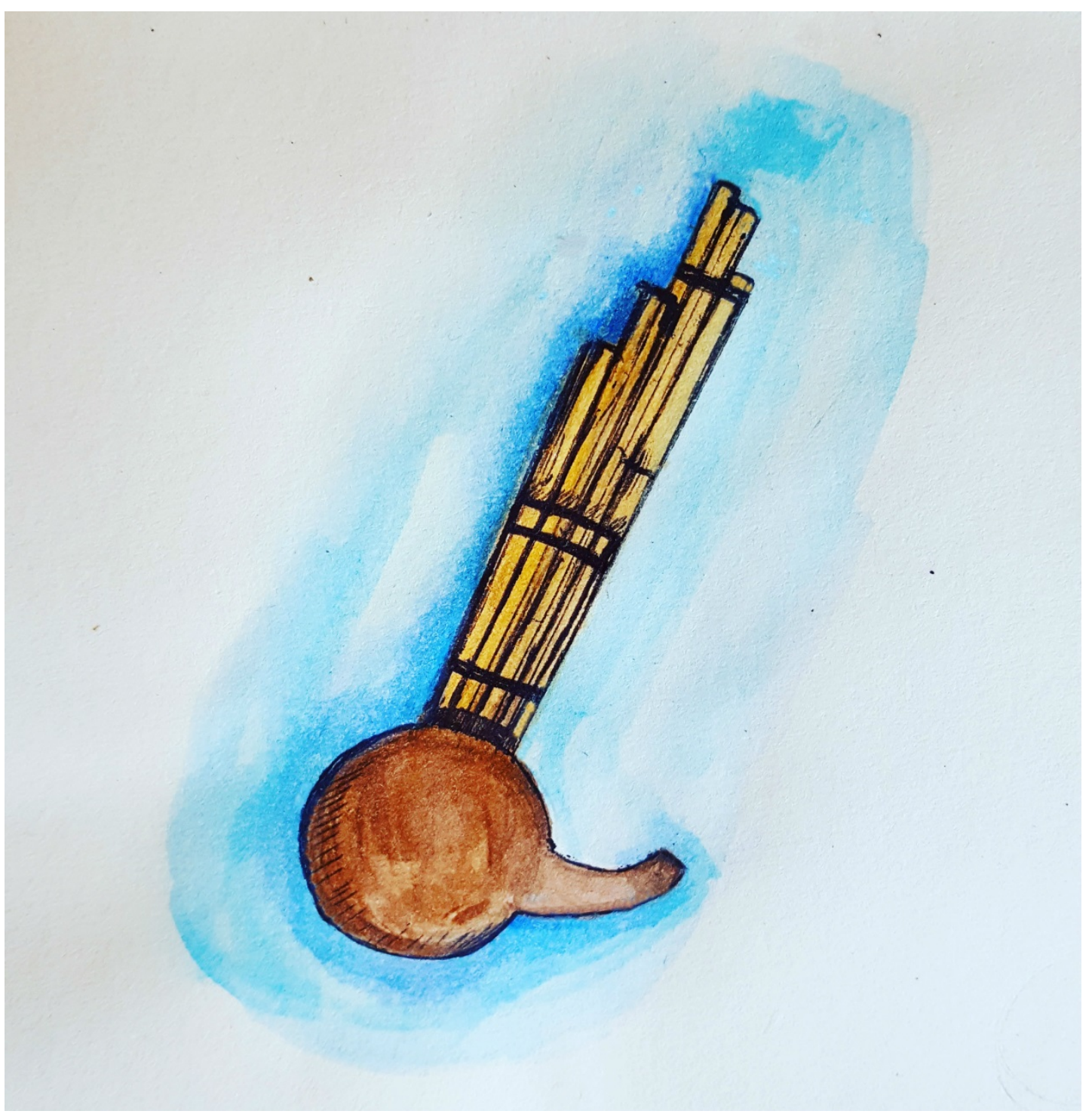

The sompoton is a Sabahan aerophone or mouth organ, consisting of 8 bamboo pipes fitted into a gourd which forms the mouthpiece. 


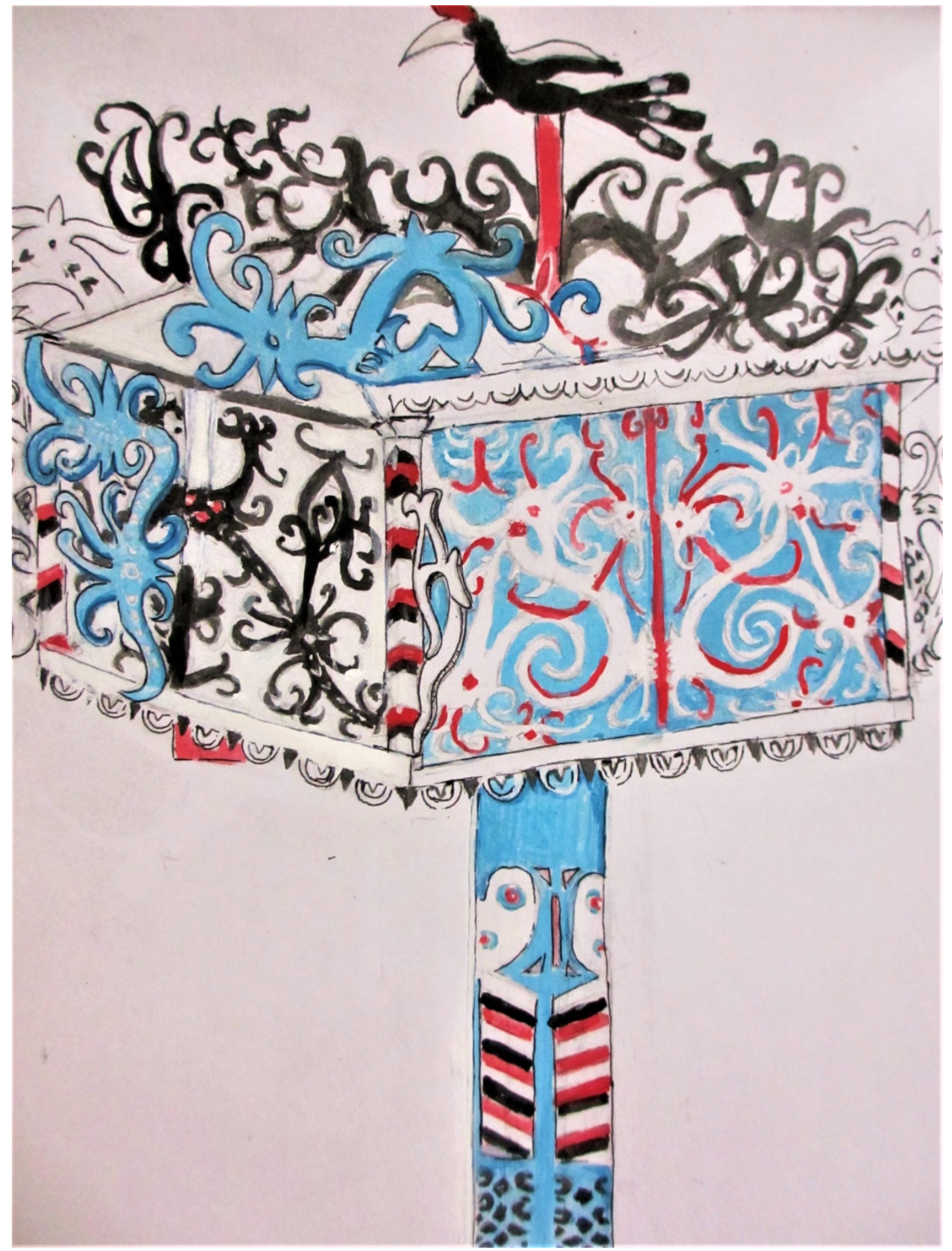

This salong or burial hut comes from the Orang Ulu displays at the Sibu Cultural Heritage Museum. Salong huts are elaborately carved from hardwood, and are used to inter the remains or local aristocrats. 


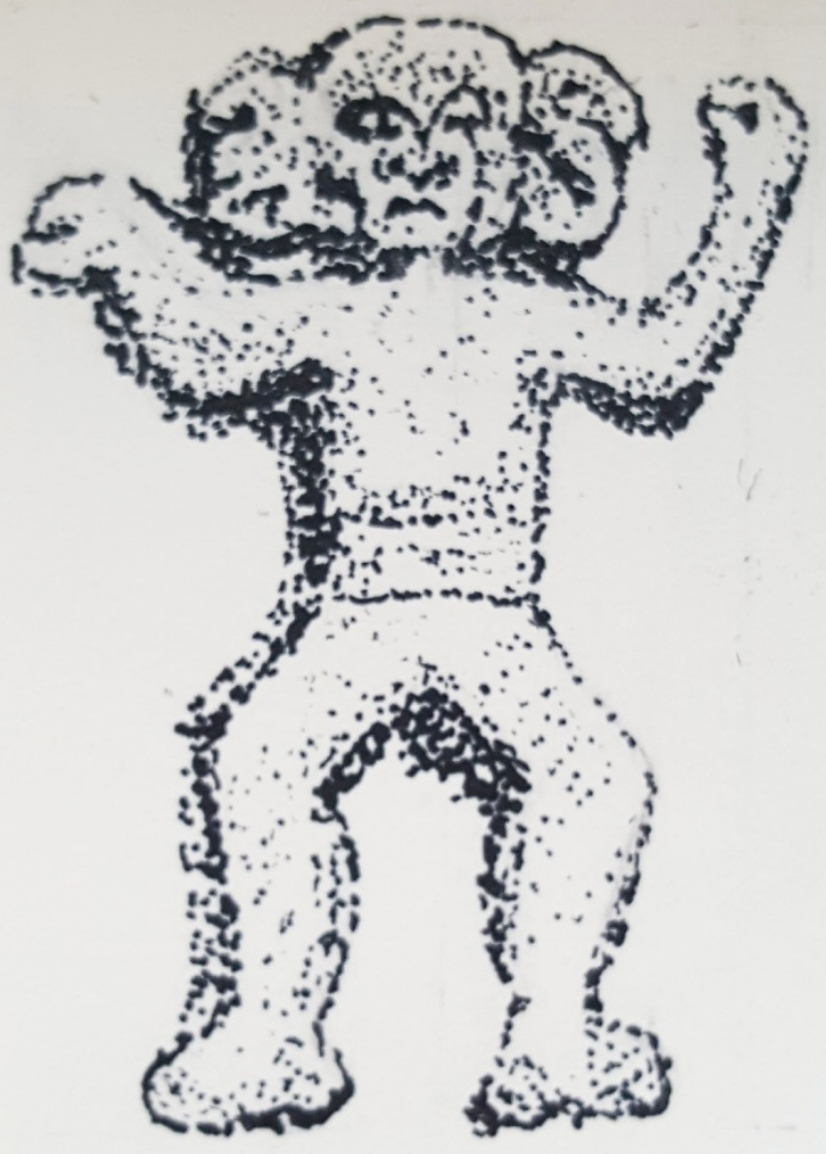

Outline of a carved stone (batu narit) near Pa' Bangar in the Kelabit Highlands. 


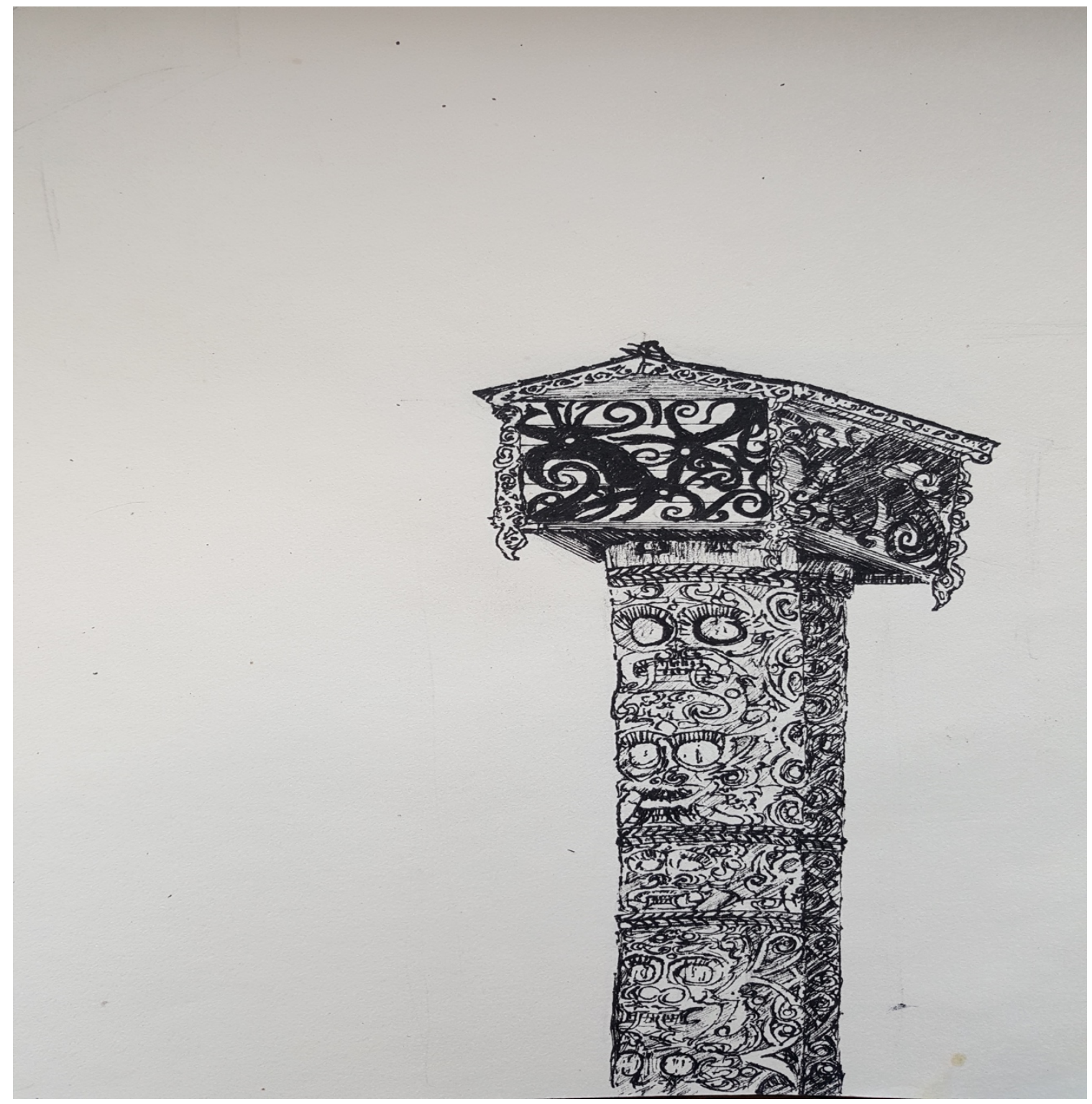

This is a double-trunk burial pole and hut (salong) from Long Segaham, Ulu Belaga which is now erected outside the Sarawak Natural History Museum in Kuching. 


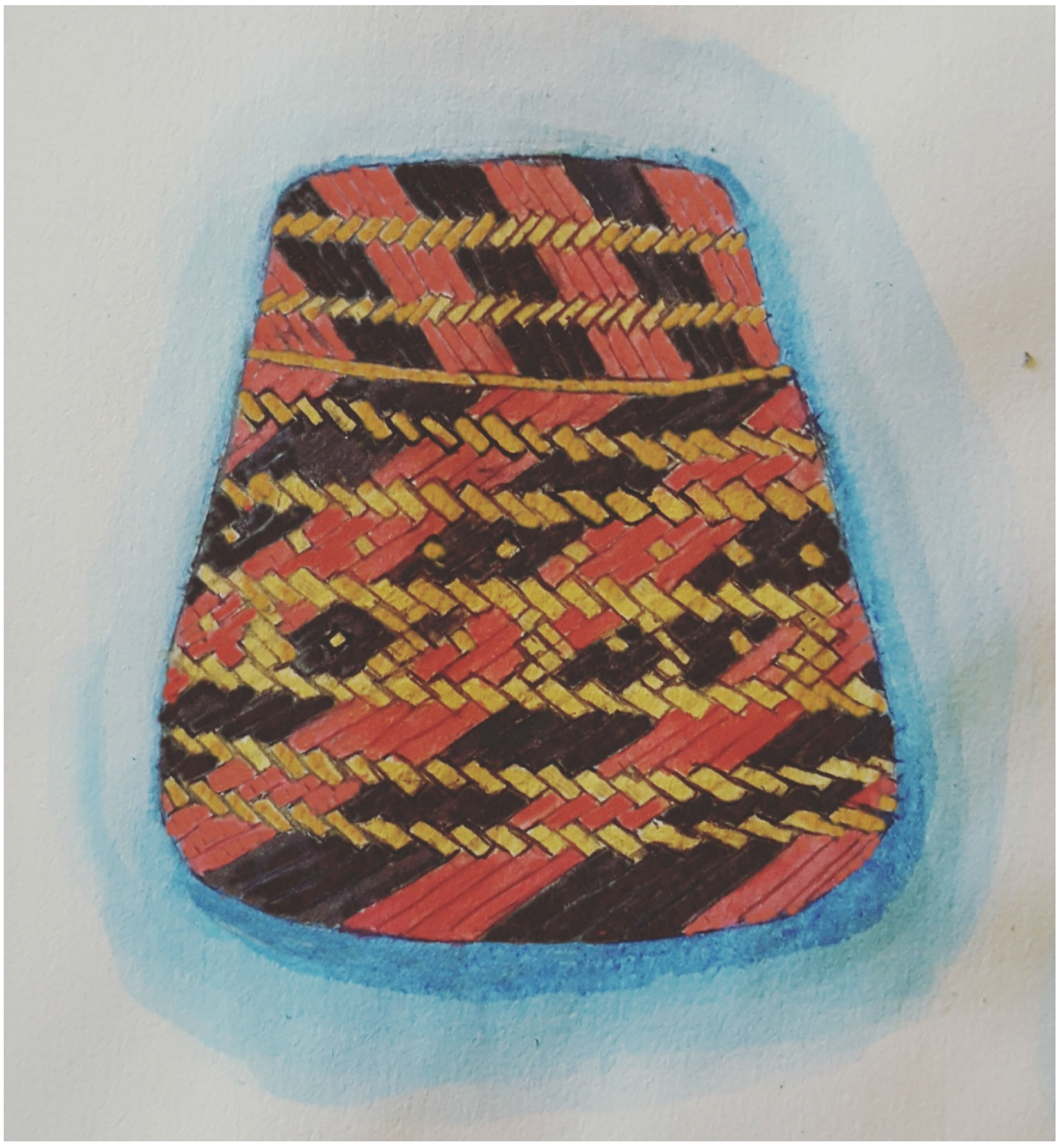

An example of Melanau basketry, which often incorporates black, red and tan colour schemes. 


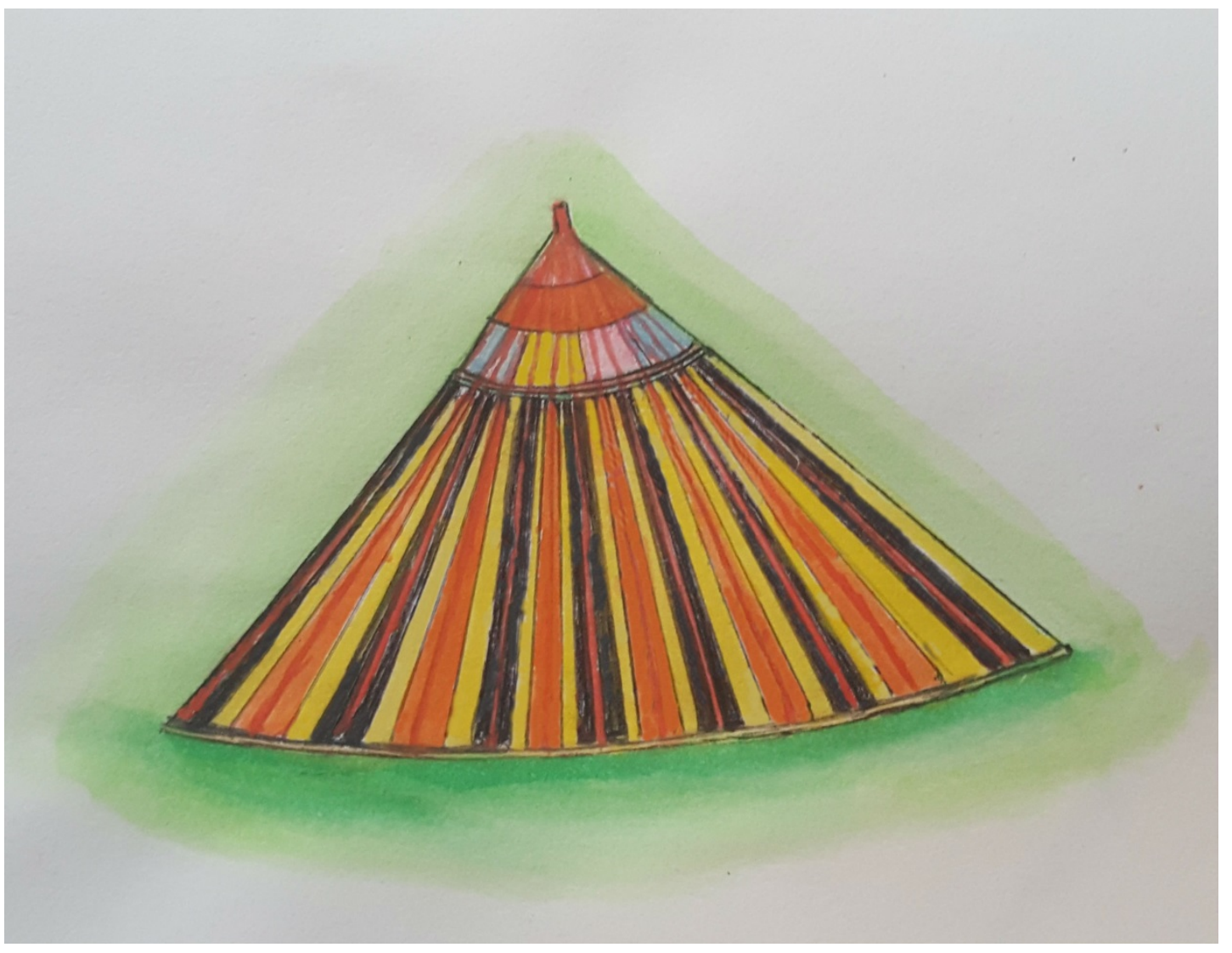

Terendak (or tapou) are the conical sunhats woven from sago palm leaves by the Melanau. One of the better-known varieties of sunhat, pictured above, is known as the terendak igan. 


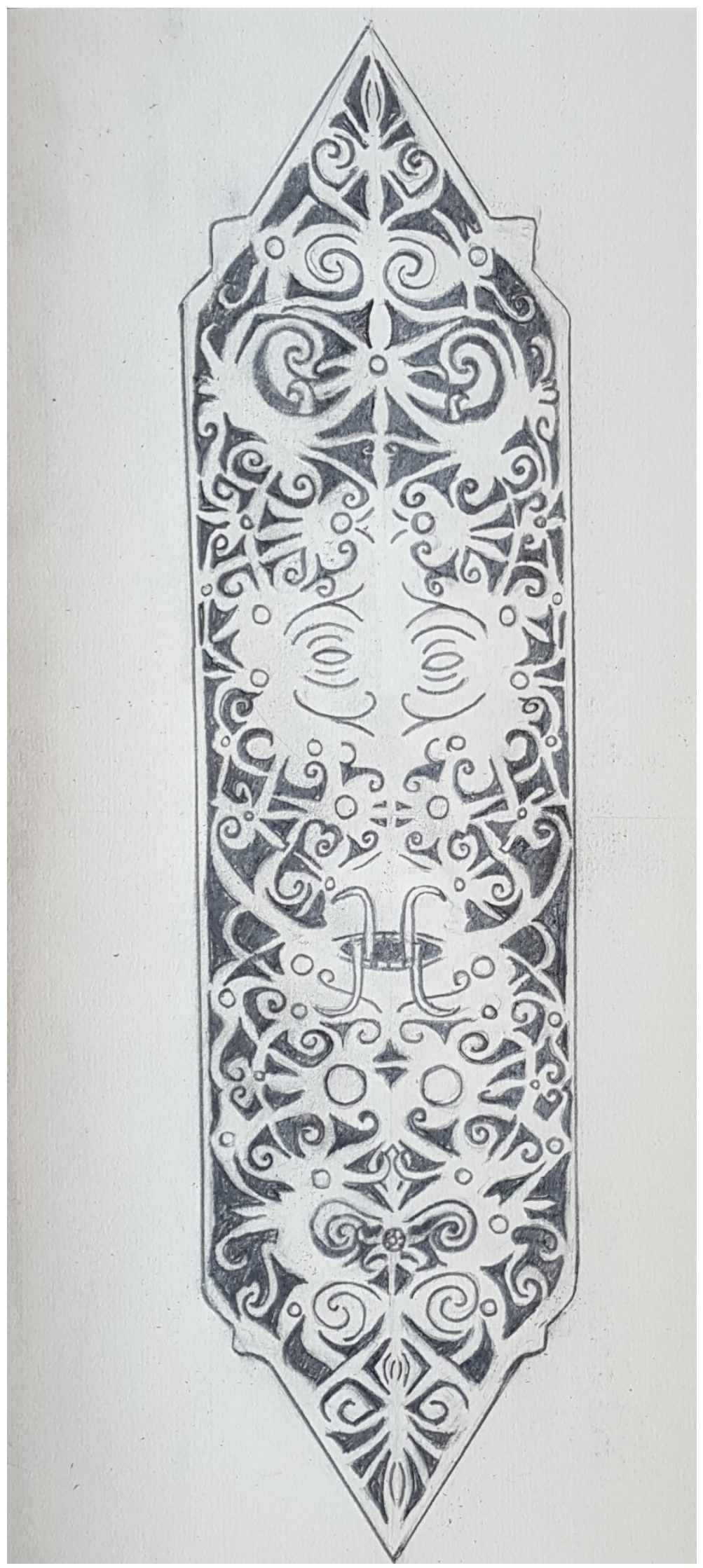

An intricately designed kelebit war shield, from the Orang Ulu displays at the Sibu Cultural Heritage Museum. 


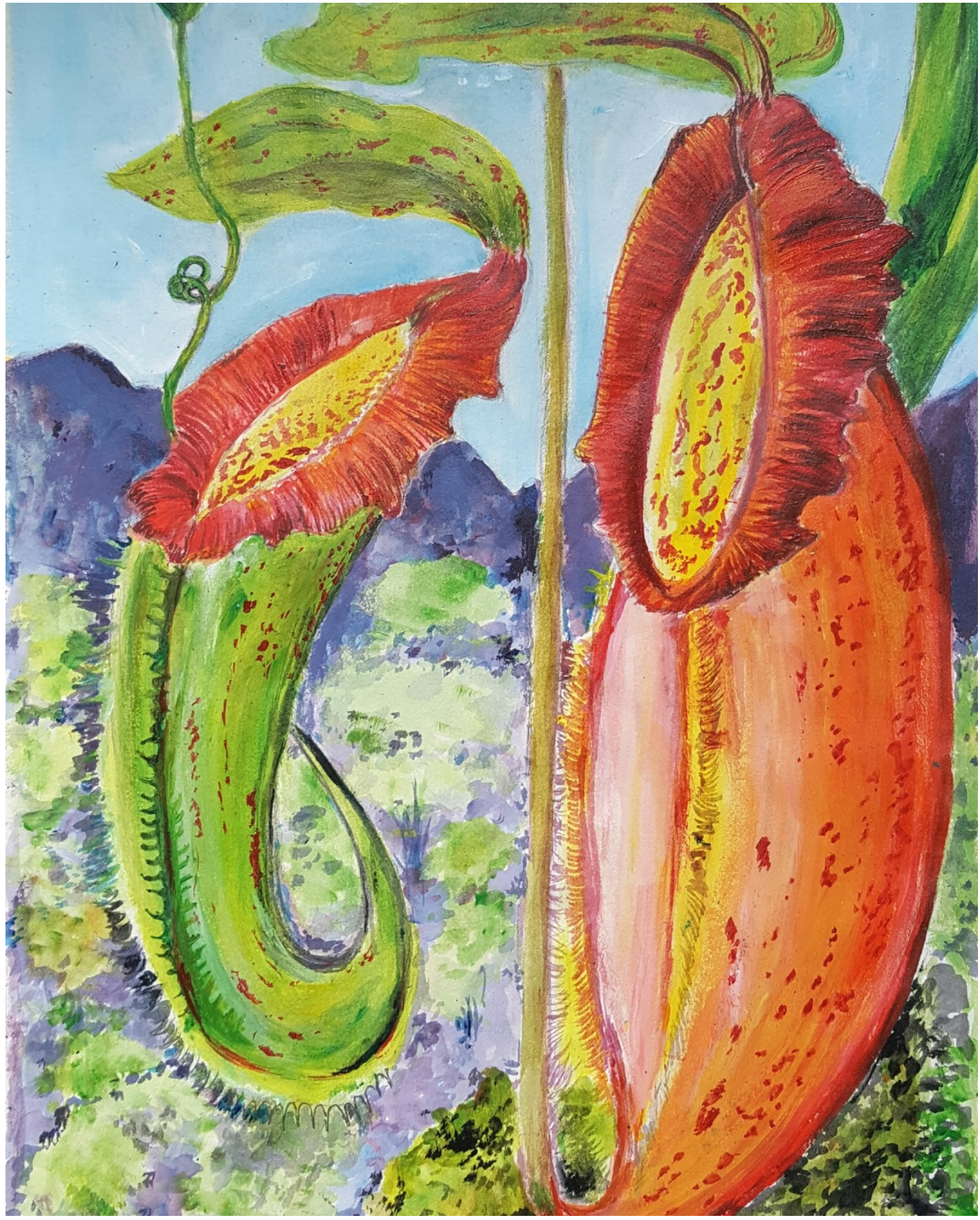

The Miss North's pitcher plants (Nepenthes northiana) are endemic to Borneo. The above is copied from a (ca. 1876) painting by Marianne North, after whom the species is named. 


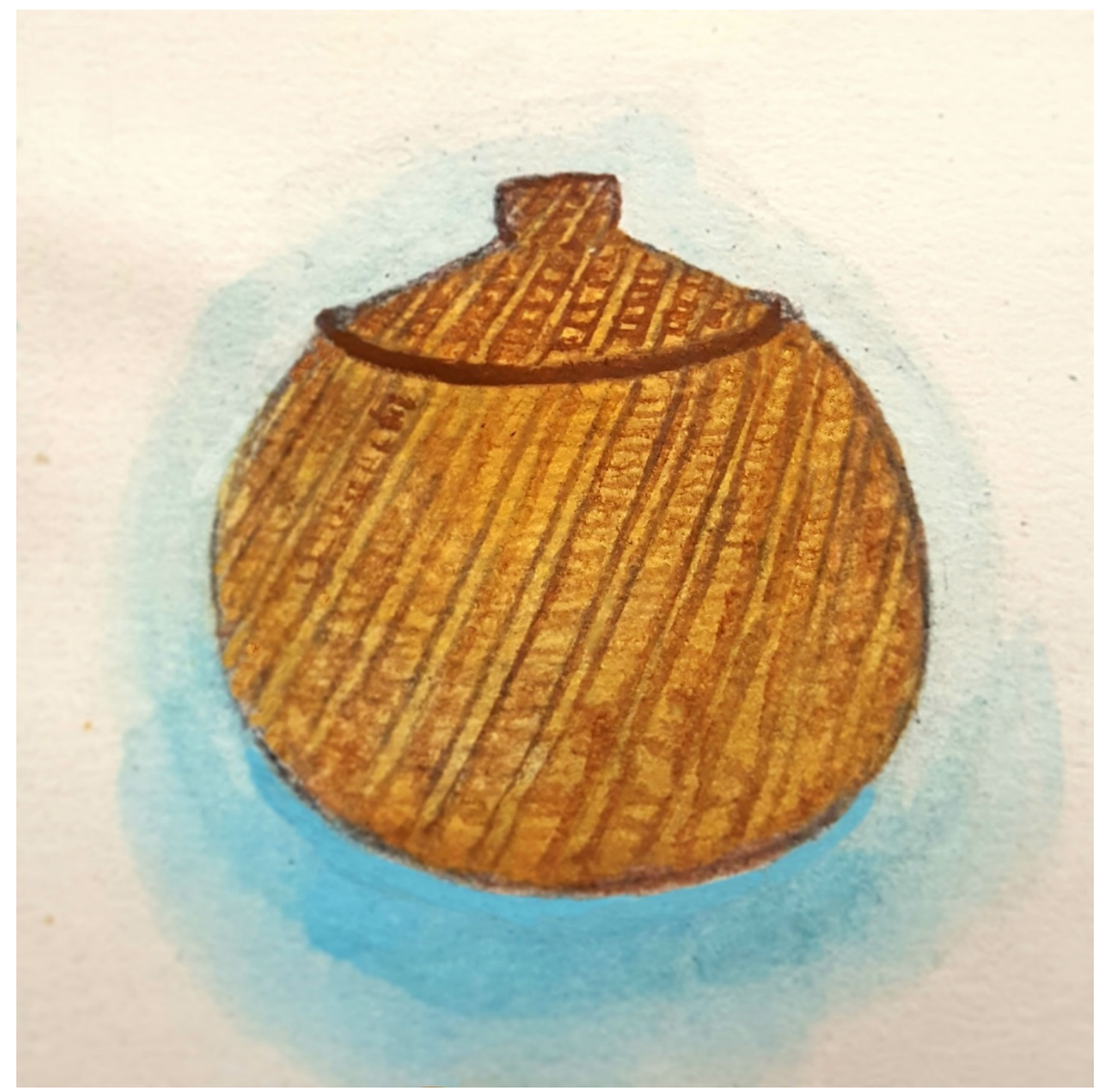

Rinago refer to a variety of coil-work baskets woven by the Rungus in Sabah. Above is a depiction of the rinago gasing. 


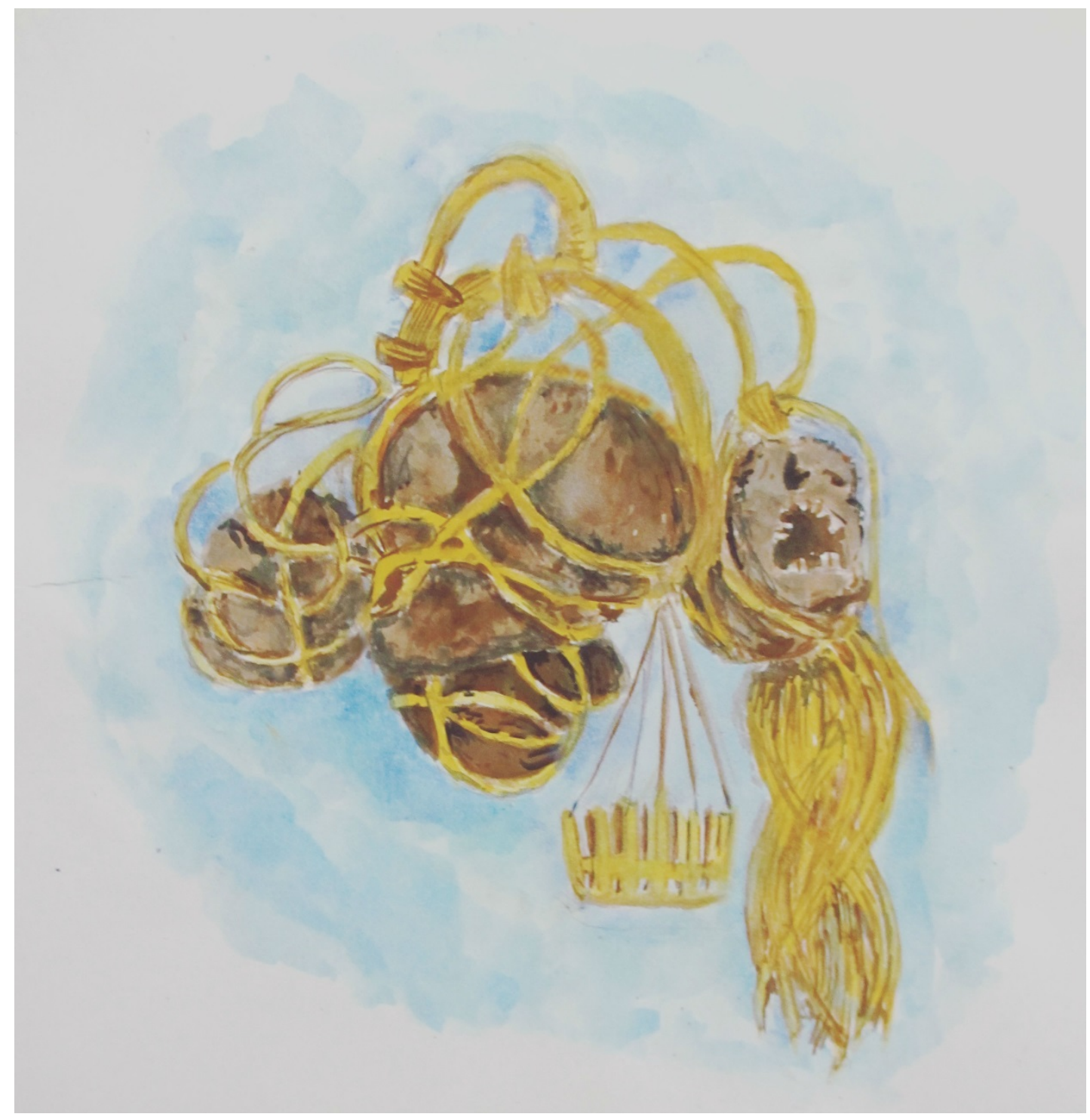

The ability to "take heads" was once a sign of bravery among the Iban, and headhunted skulls were often retained as trophies. Although headhunting is no longer practised today, the skulls (or antu pala) continue to be treated with respect as they are believed to hold the spirit of the deceased. 


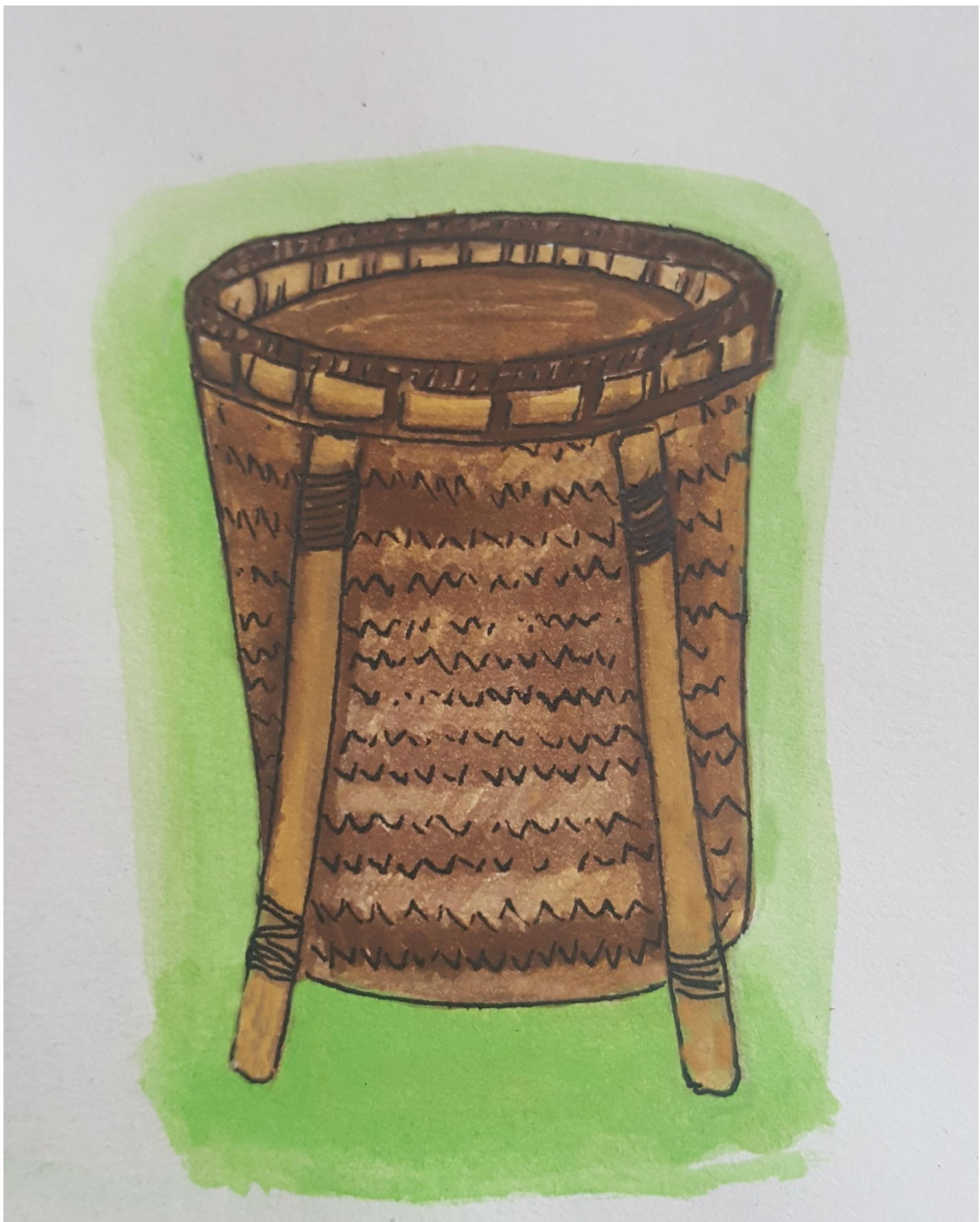

Takinan are Sabahan baskets best characterised by the 4 rattan stands which support them. 


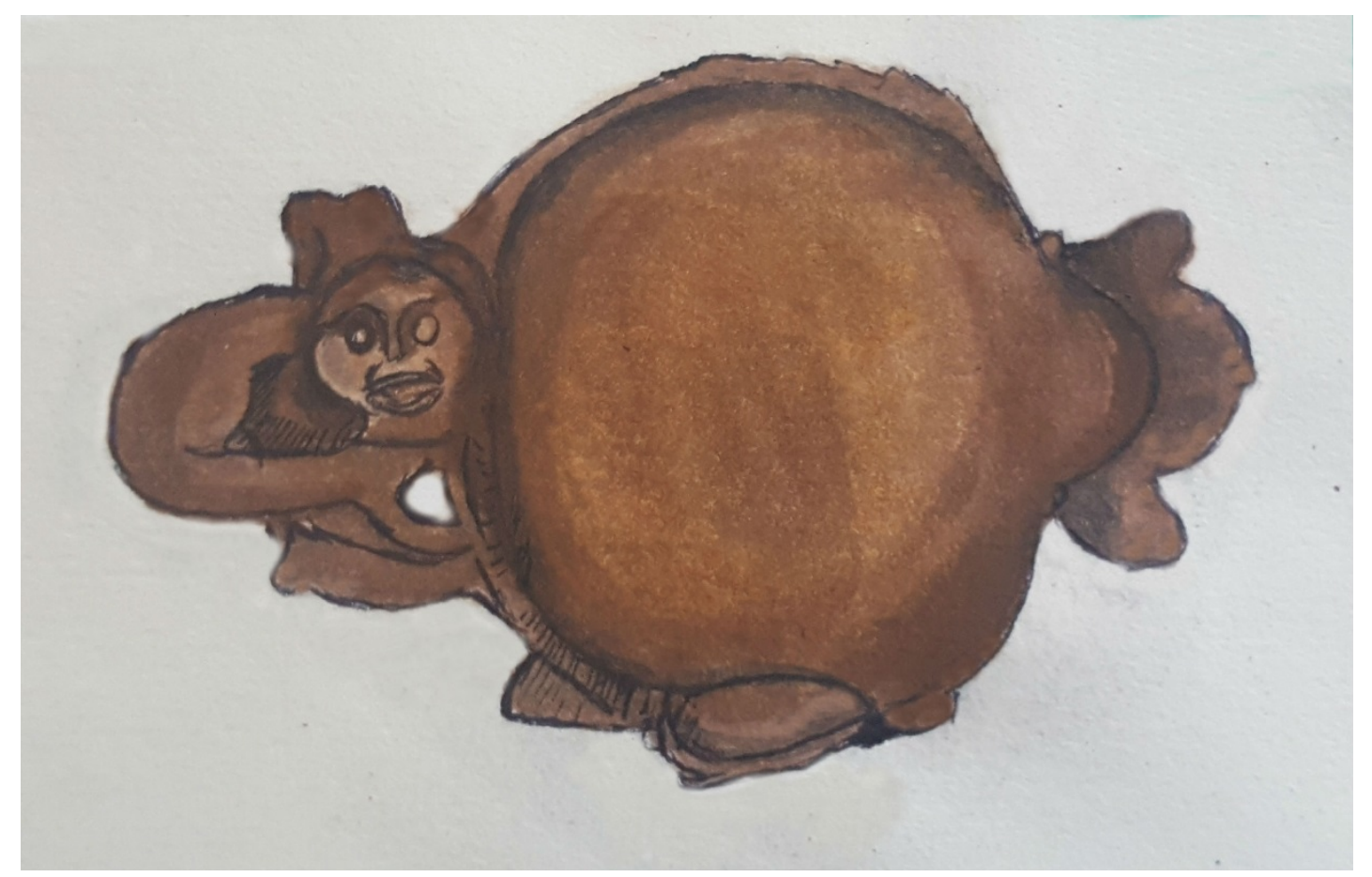

A wood-carved Berawan food bowl from the collections of the Sarawak Museum. 


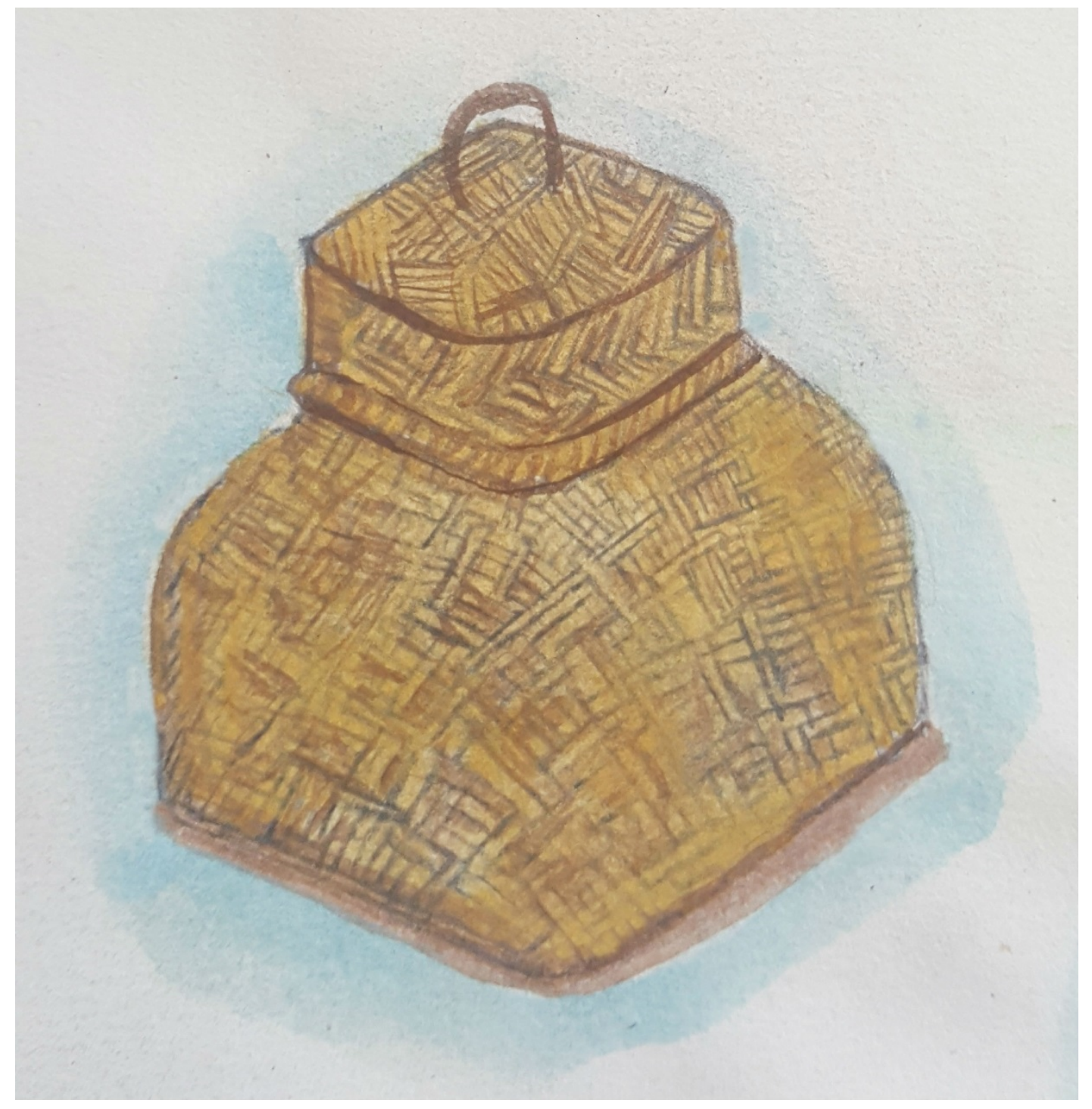

Bayung are multipurpose baskets woven by the Dusun from a type of wild grass known as bemban (Donax canniformis). 


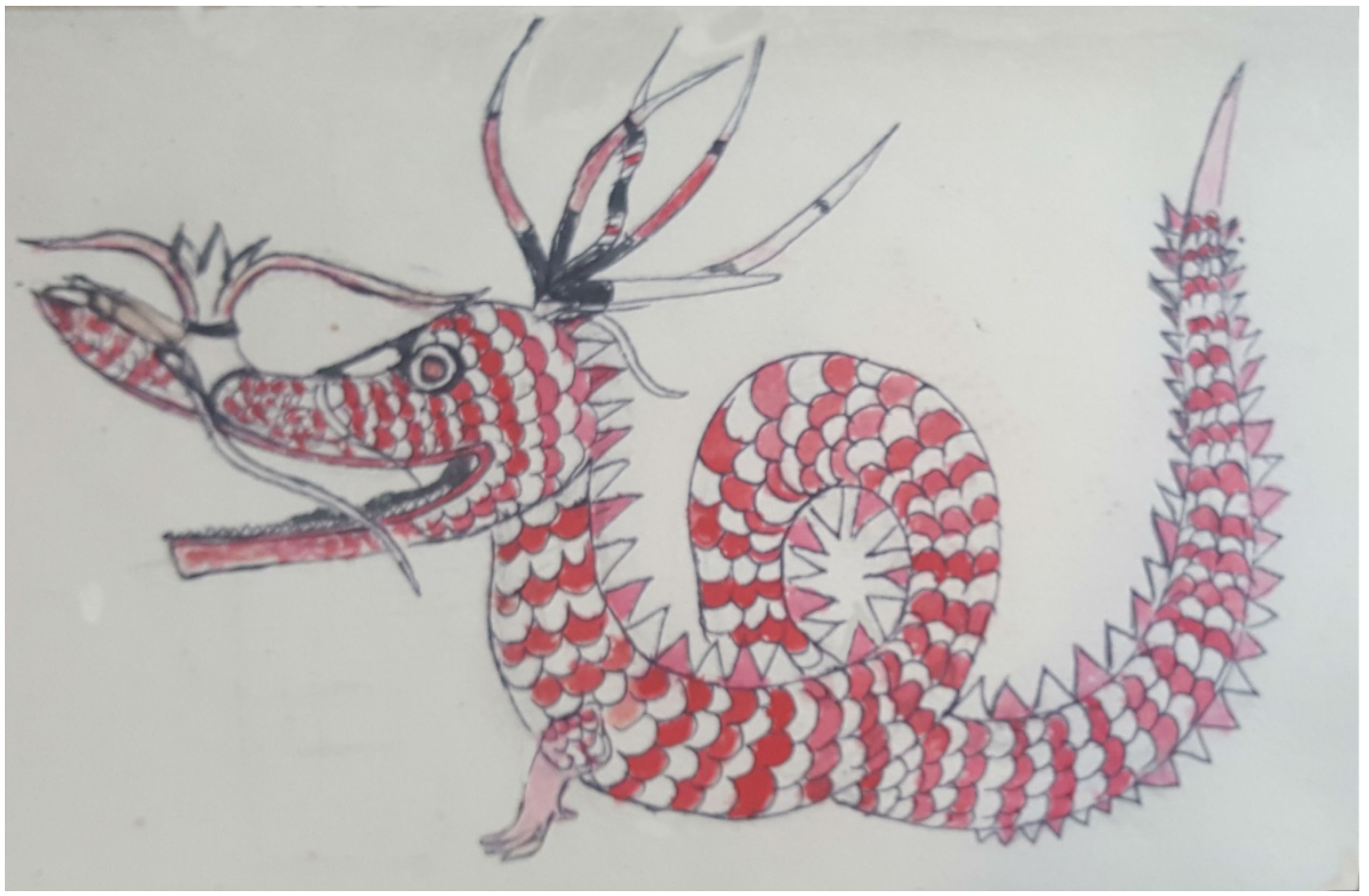

Belum or dakan are carved wooden effigies made for their use in traditional Melanau healing rituals. The images vary based on the carver, local traditions and the type of spirit. Depicted above is the naga sebalun on display at the Sarawak Museum.

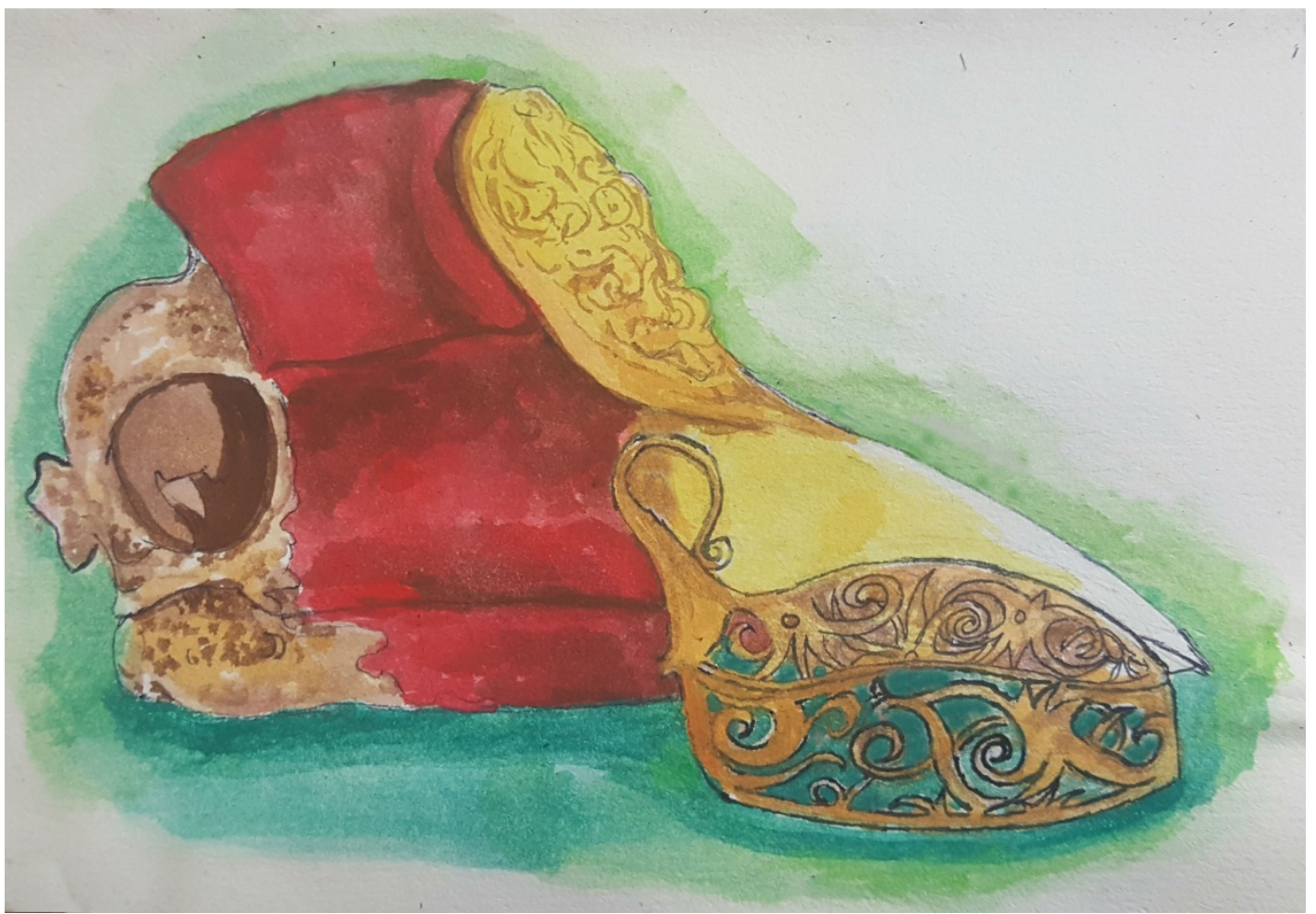

The solid casque of the helmeted hornbill makes it a prized commodity, and it was traditionally used to carve accessories such as ear pendants. 


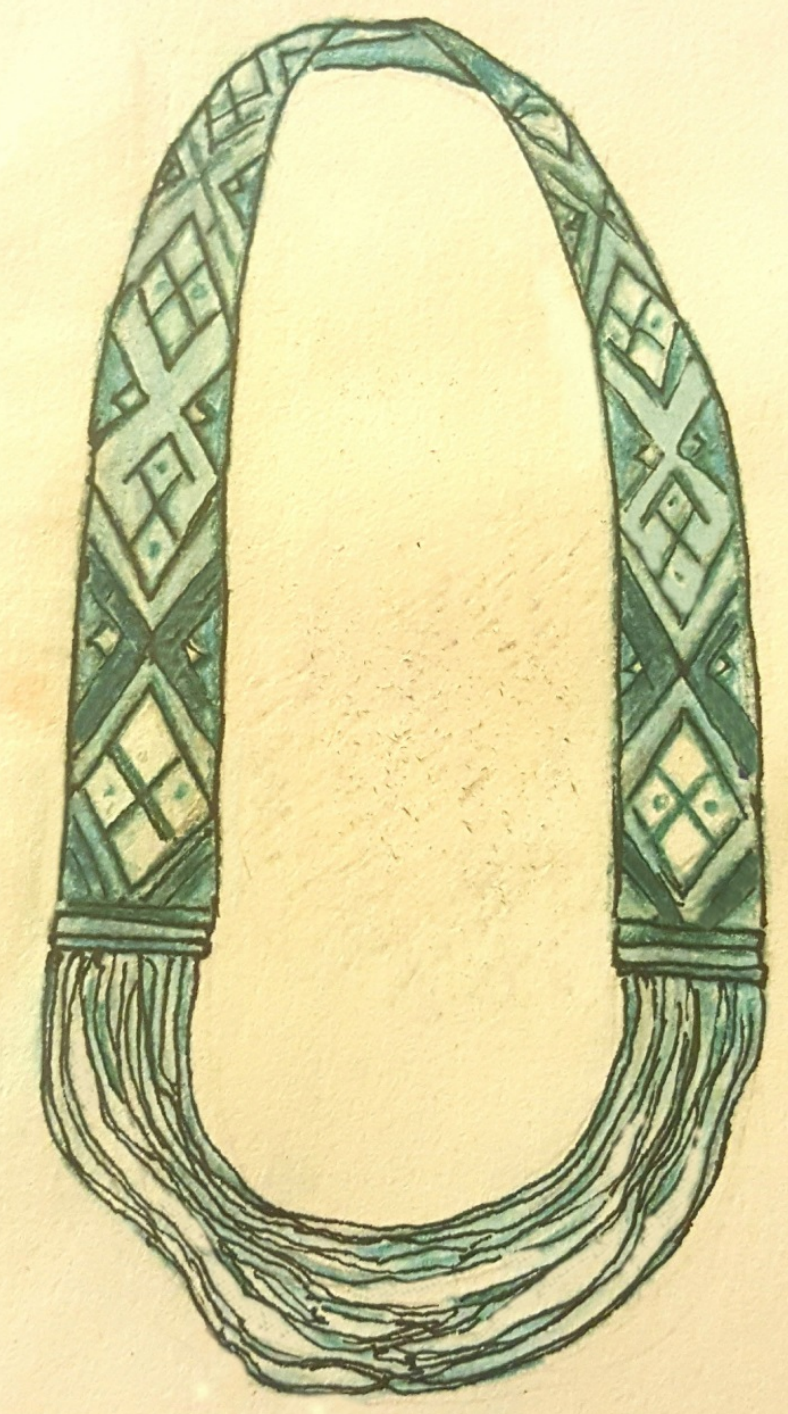

One of the countless examples of Bornean beadwork, pinakol are bandoleer-type belts worn over the torso and are part of the traditional attire of the Rungus in Sabah. 


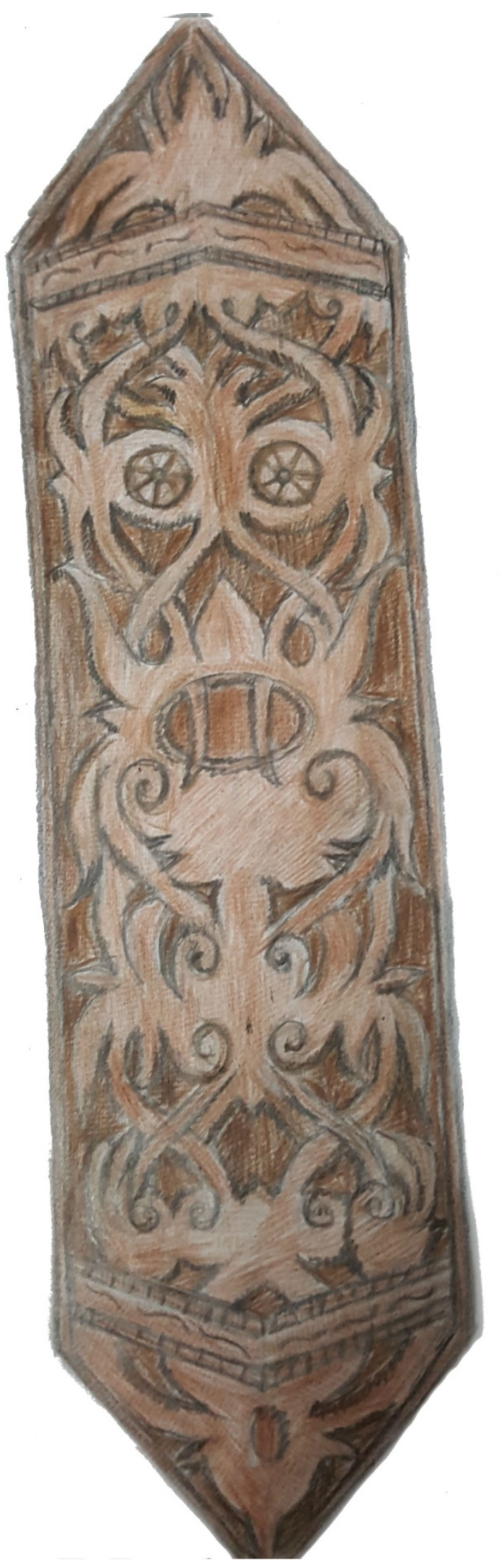

This is the carved wooden terabai (war shield) from the Iban displays at the Sibu Cultural Heritage Museum. 


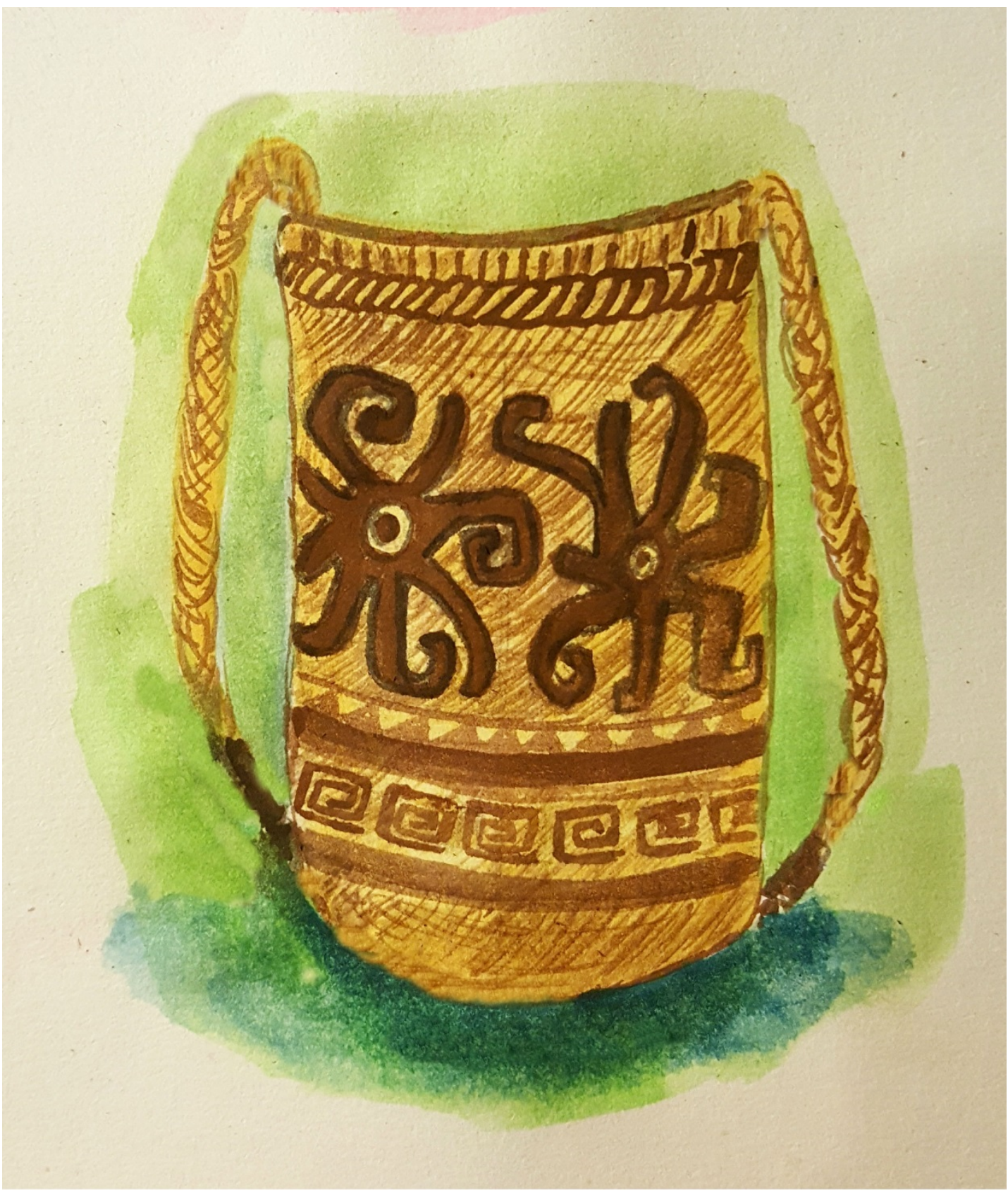

Ajat baskets are traditionally woven from rattan by the Penan. 


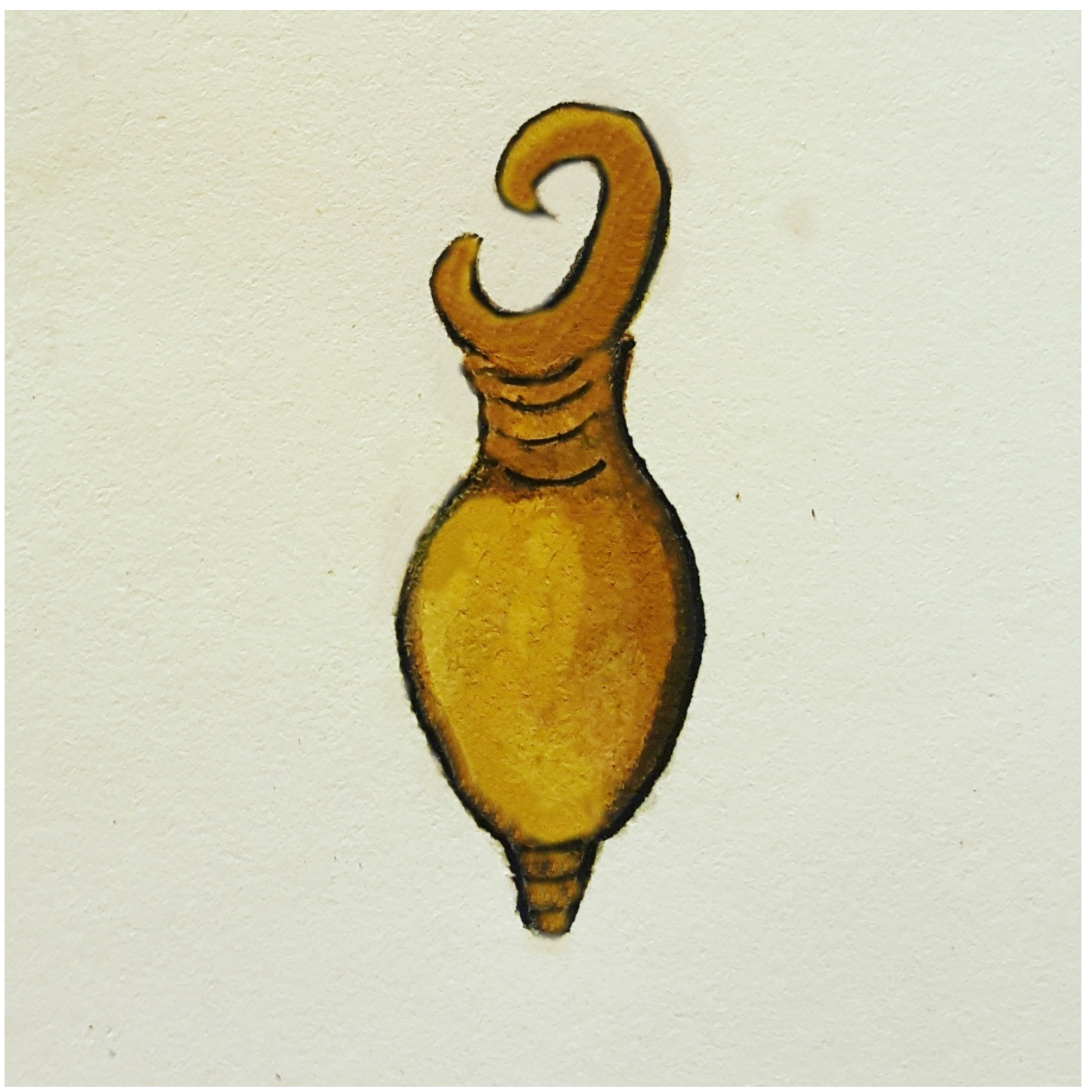

The stretching of ear-lobes for aesthetic purposes was often achieved through the use of brass or lead ear-weights. The practice is typically started when the individual is a child, with more weight being added to the lobes as he or she gets older. 


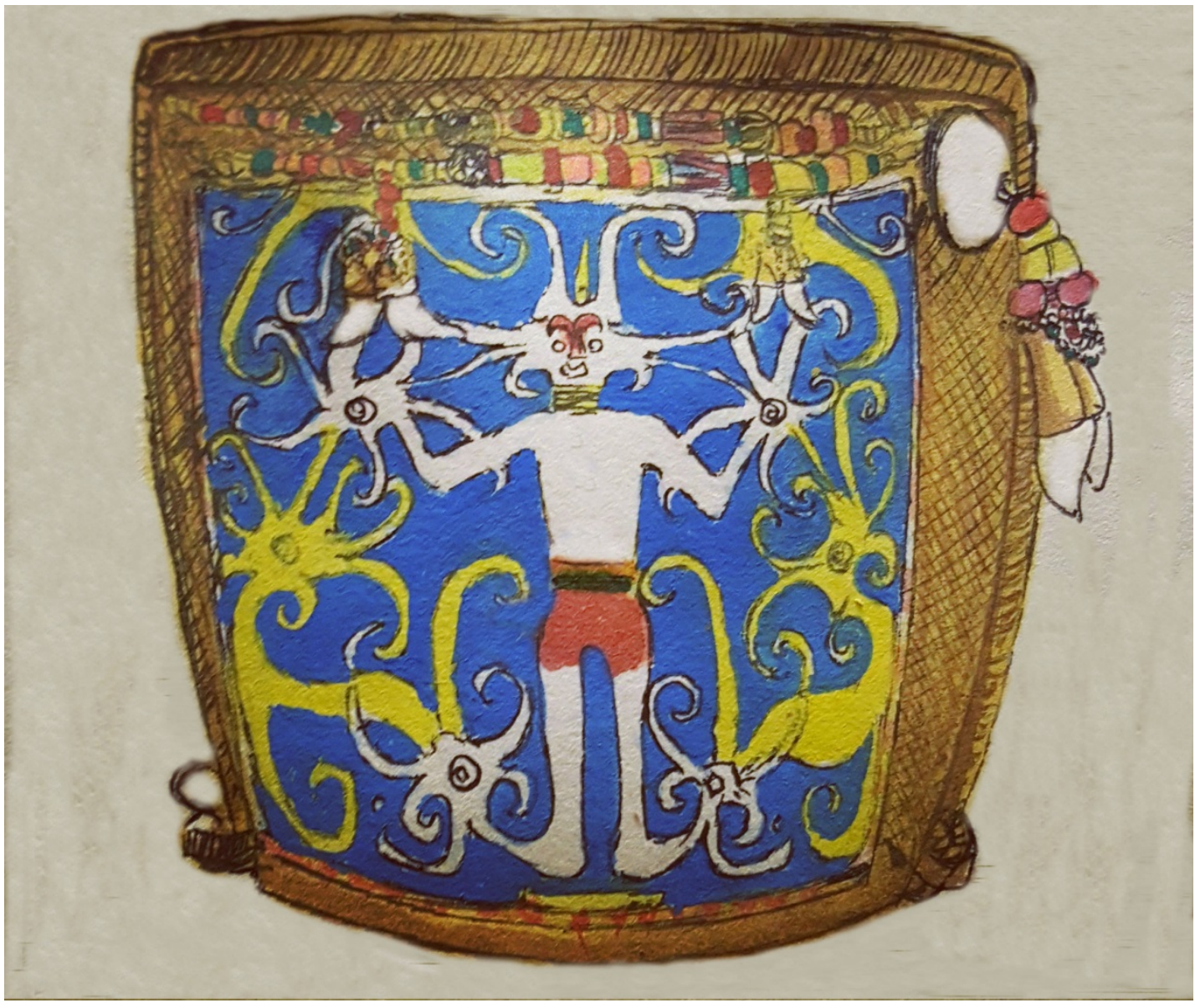

This $b a$ or baby-carrier incorporates both basketry and beadwork, and is part of the Urang Sarawak display in Kuching. 


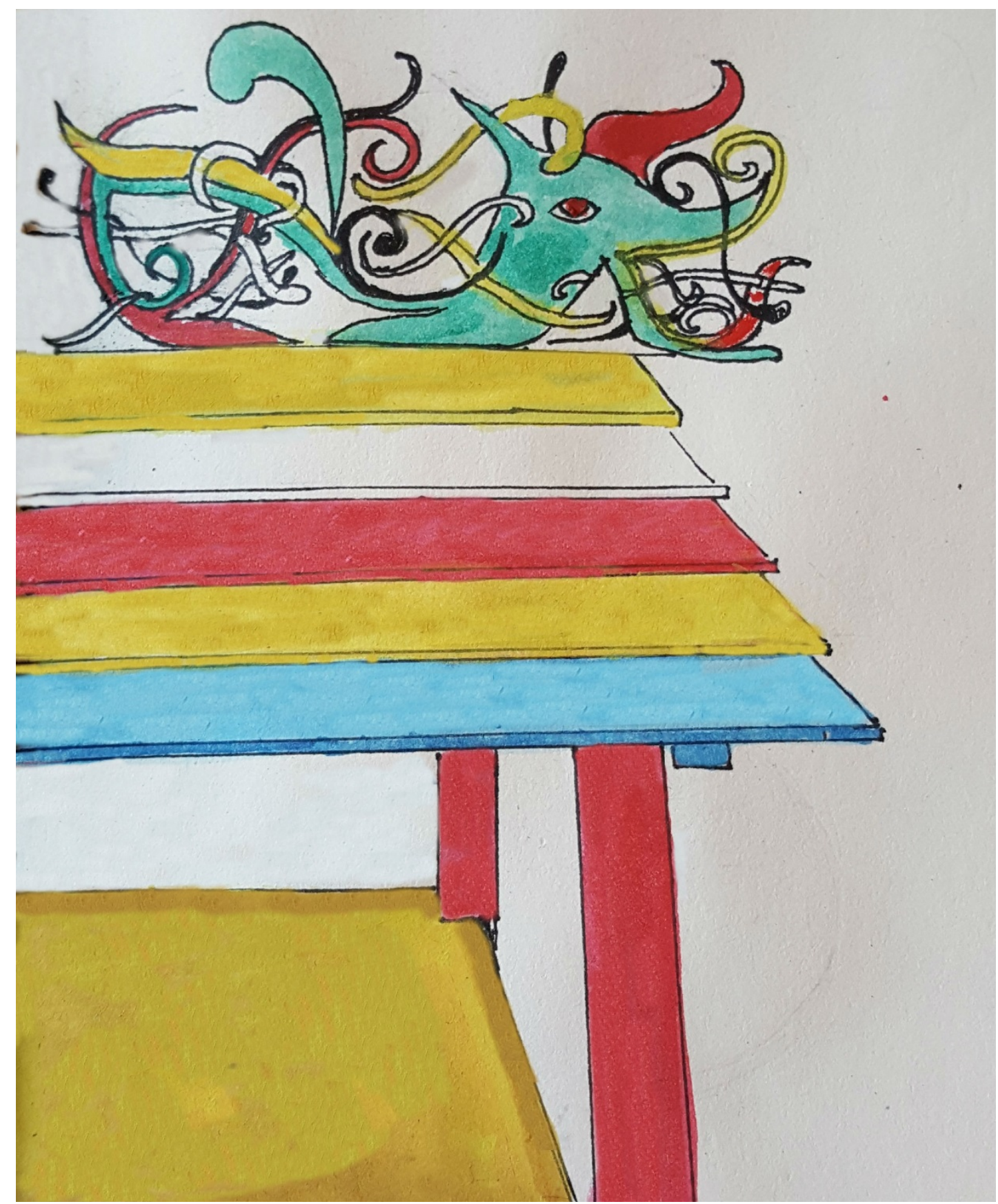

Sungkup are Iban mortuary structures which can only be carved during Gawai Antu. The example above is from the Sibu Cultural Heritage Museum. 


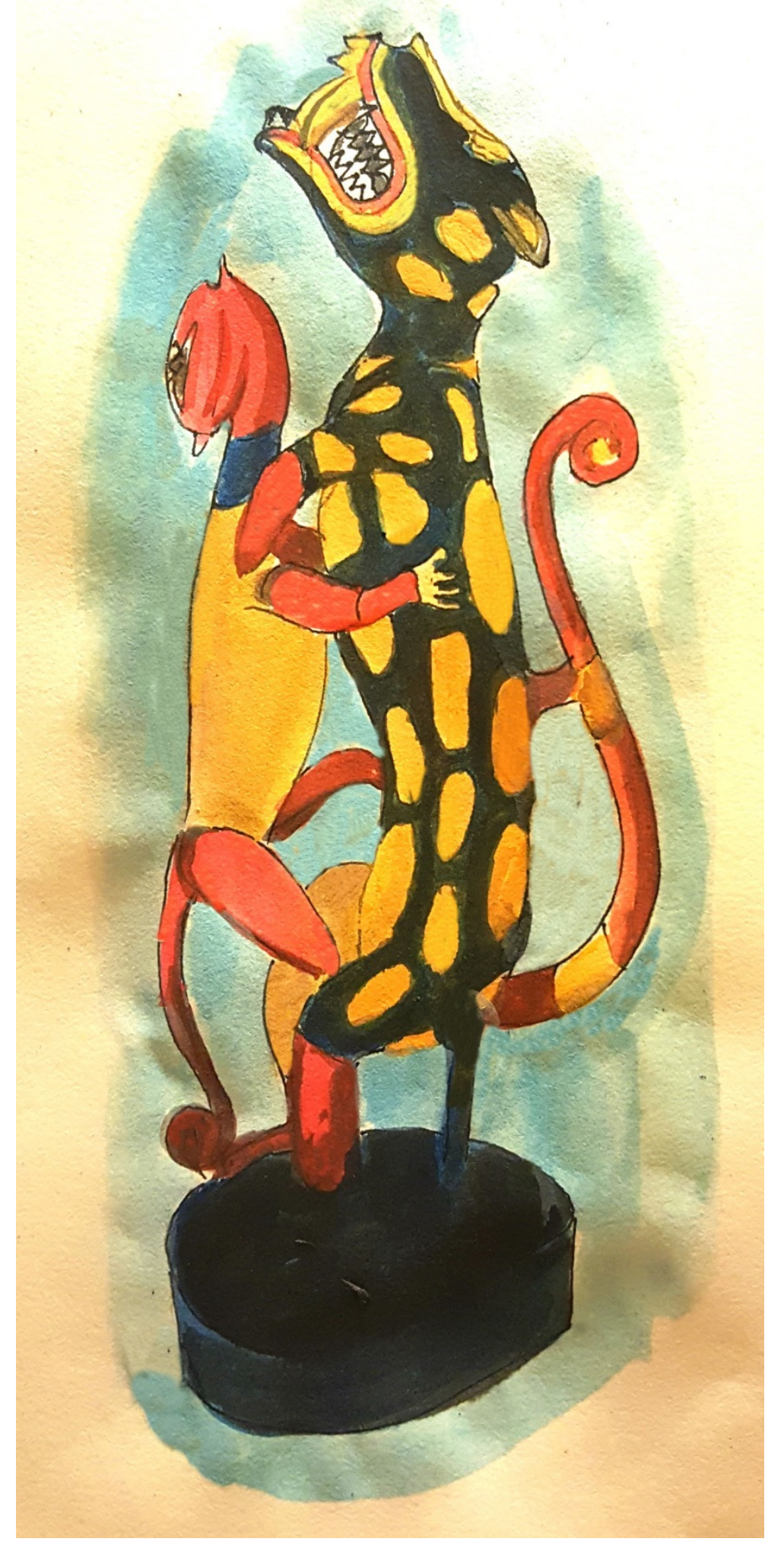

A Kenyah carving from the collections of the Sarawak Museum depicting a leopard and a dragon dog. 


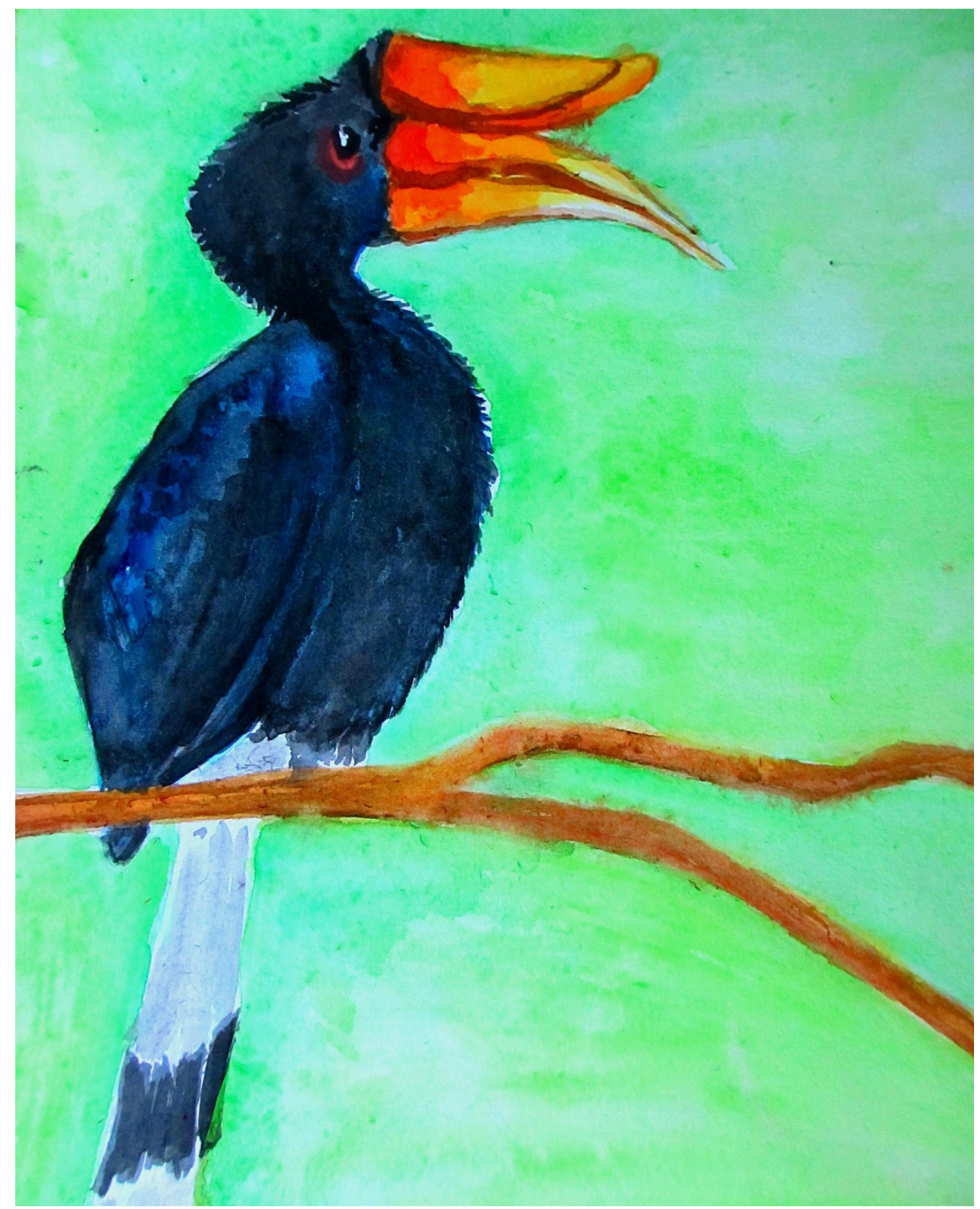

The rhinoceros hornbill (Buceros rhinoceros). 


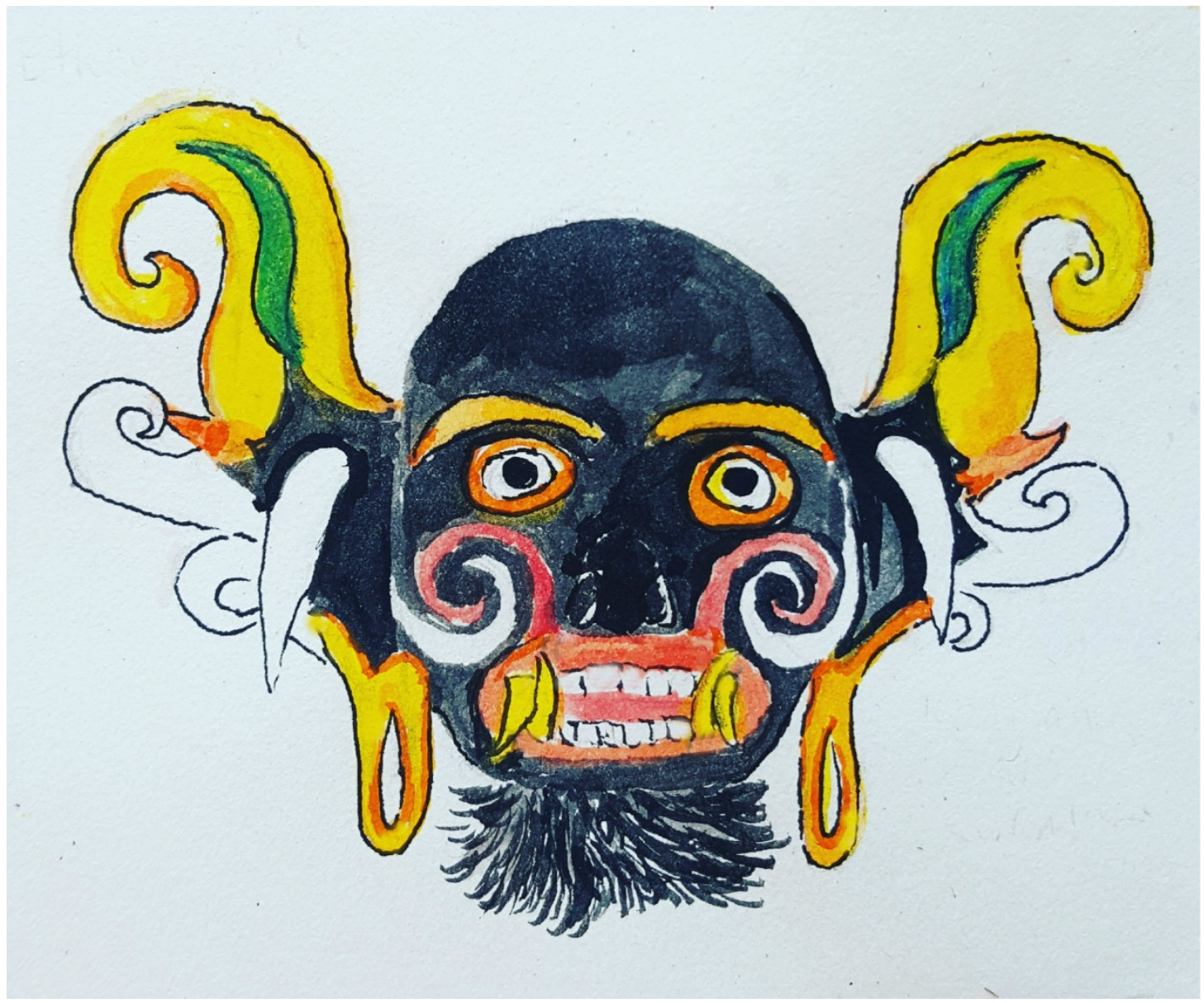

Kenyah ritual mask with protruding ears, on display at the Sarawak Museum. 


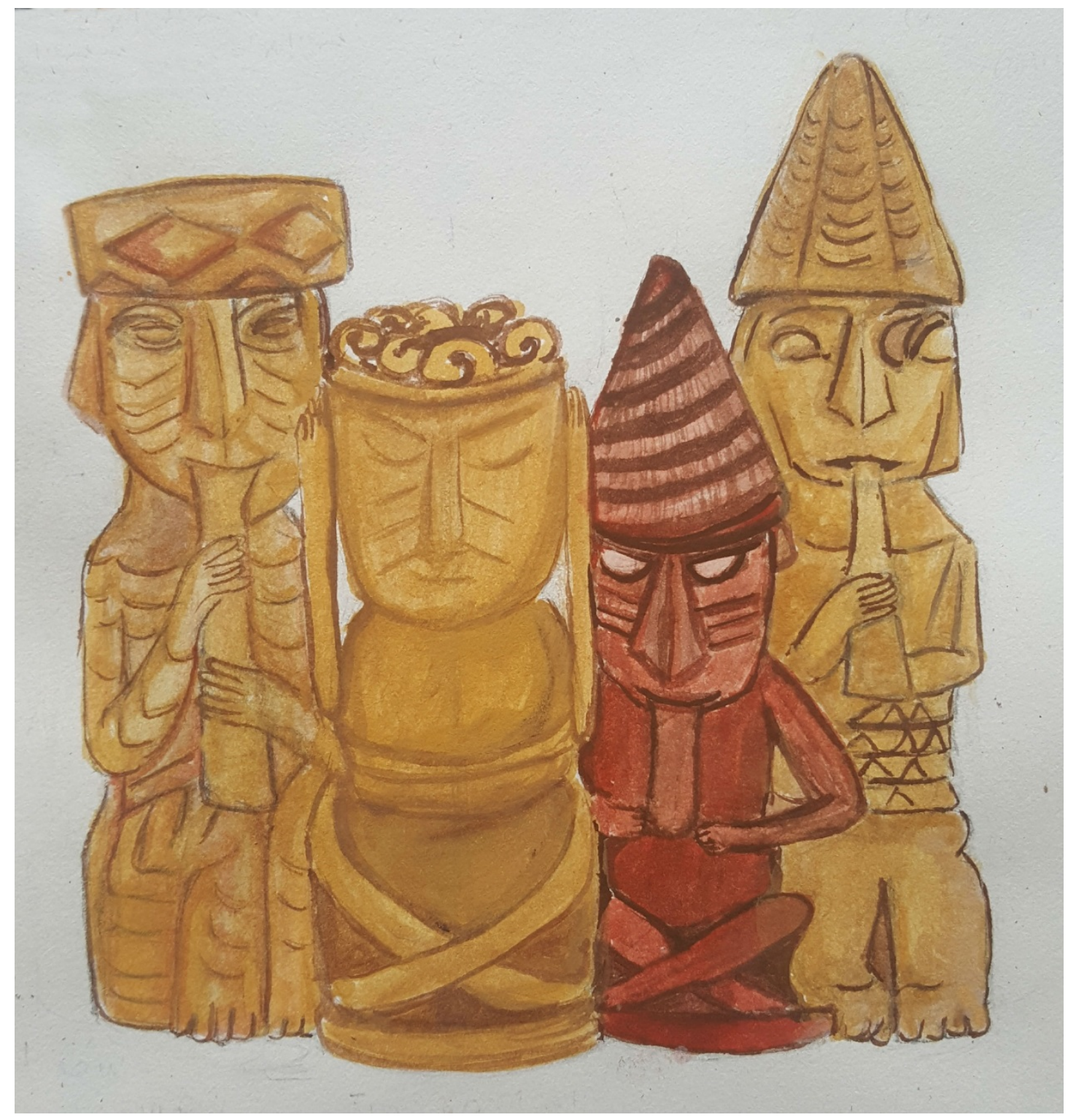

Four types of Melanau bilum. From left to right: (a) Buaw pengamou, an earth spirit from the Sarawak Museum; (b) Jin seperangin from the Sibu Cultural Heritage Museum; (c) Kulum pengamou from the Sibu Cultural Heritage Museum; (d) Kulum pengamou from the British Museum (As1994,05.52). 


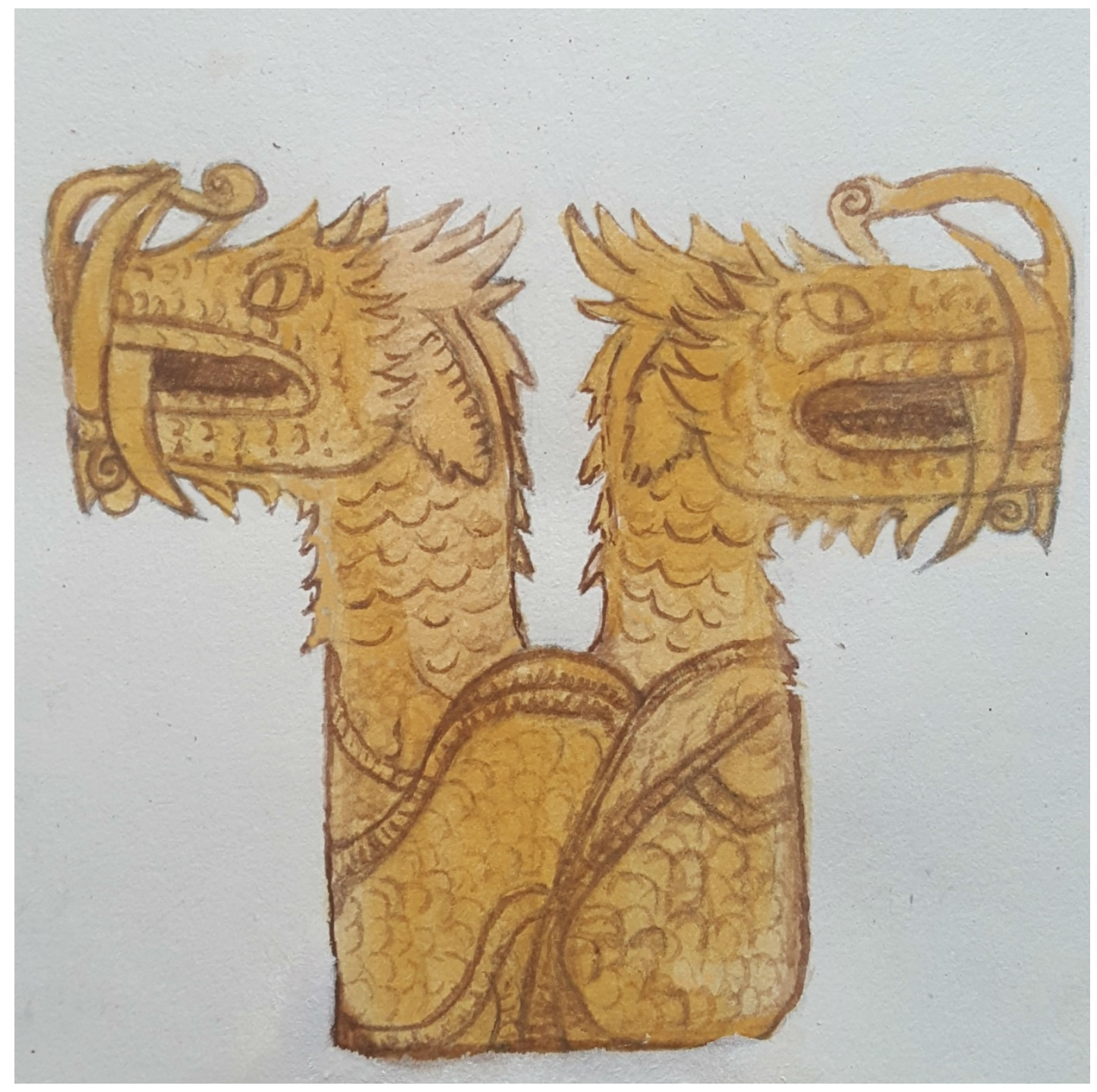

Another take on the naga sebalun, on display at the Sarawak Museum. 


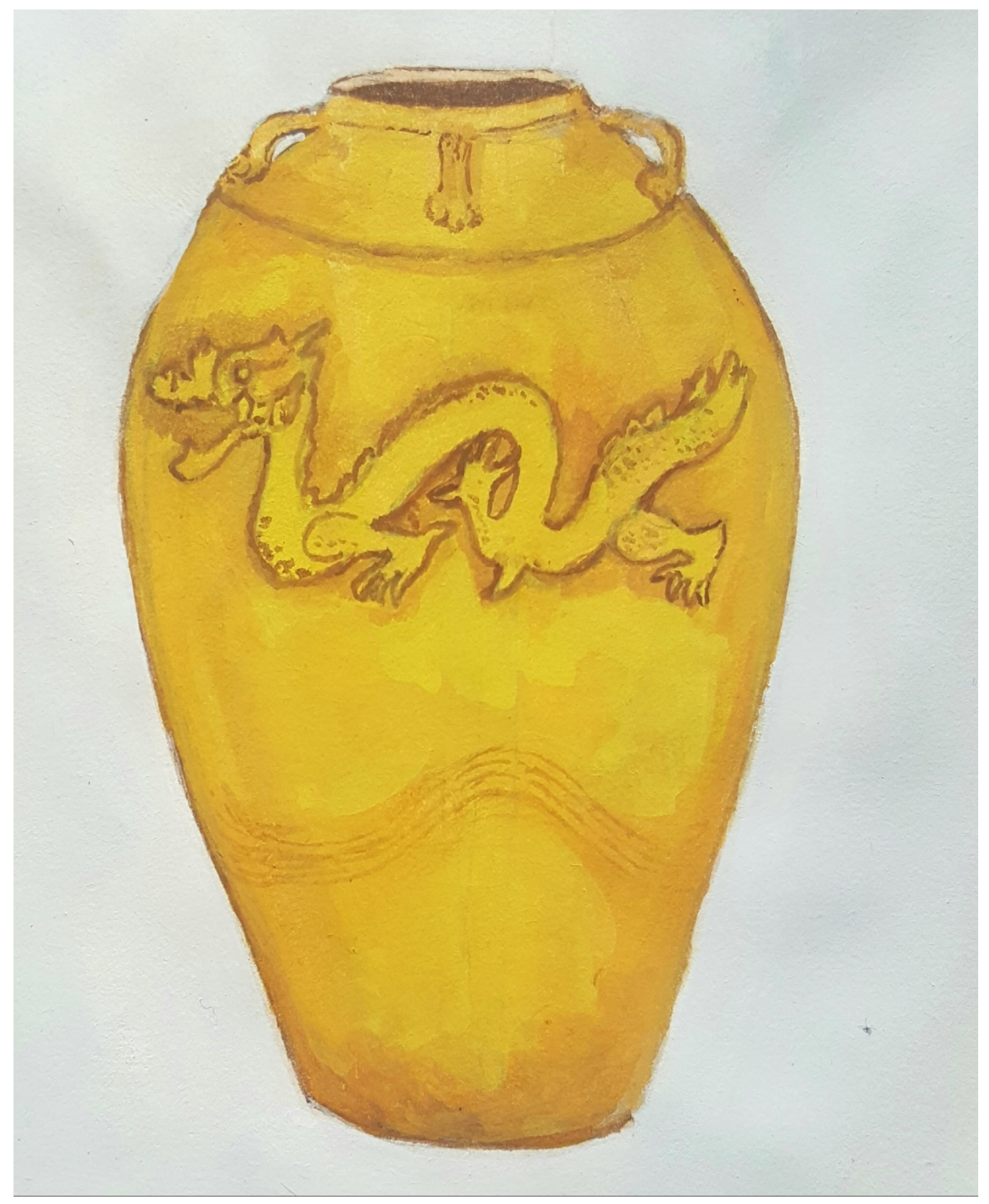

Ceramic stoneware jars depicting dragons are commonplace in Borneo, regardless of whether they are used as status symbols or as utilitarian wares; this particular jar is from a landscape design setup. 


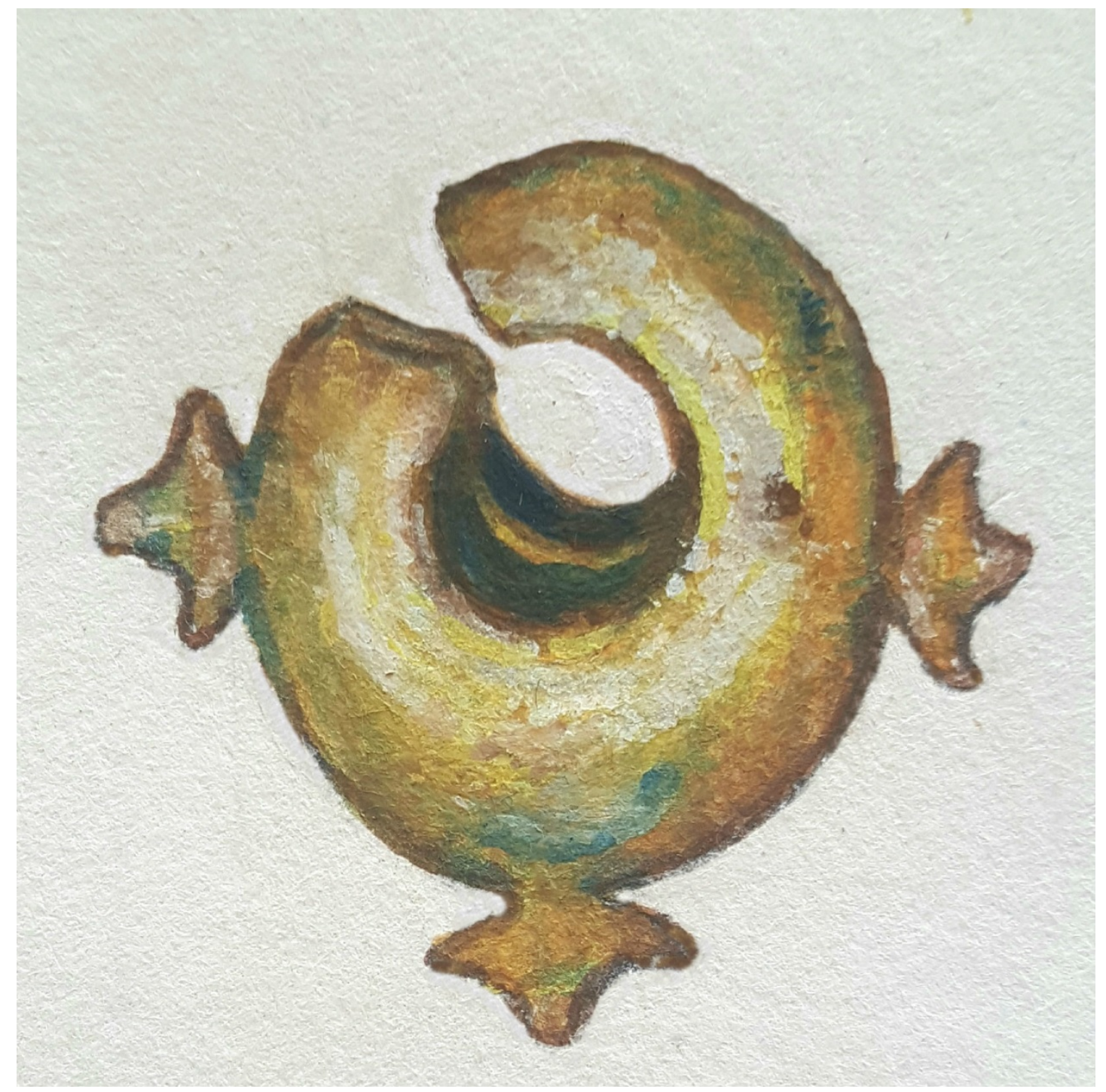

The nephritic lingling-o excavated from the Niah Caves in 1977 (after Iizuka et al. 2005). 


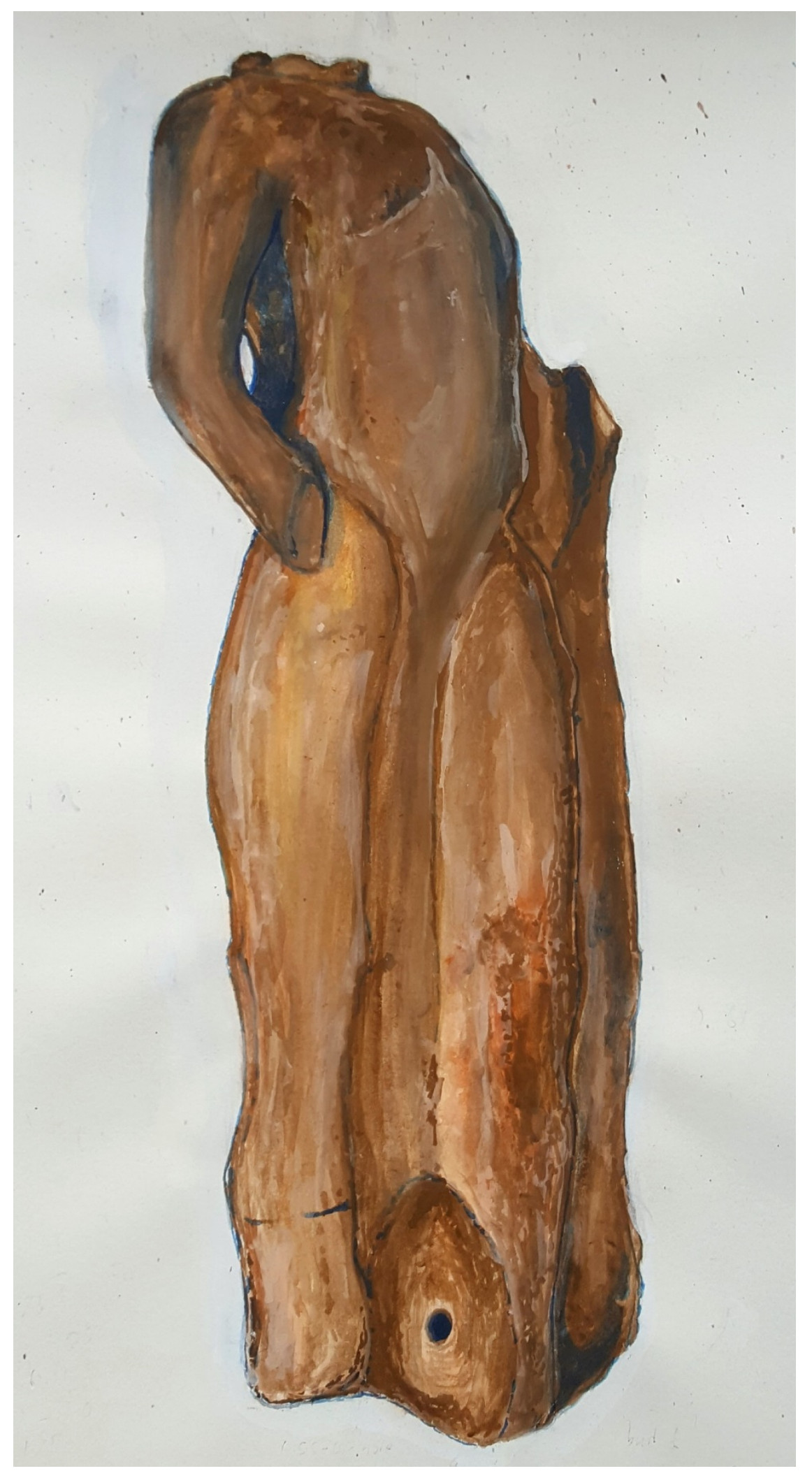

This is the headless stone Buddha from Bukit Maras, Santubong made in the Gupta tradition. (photo reference: @sarawakmuseumcampus on Instagram) 


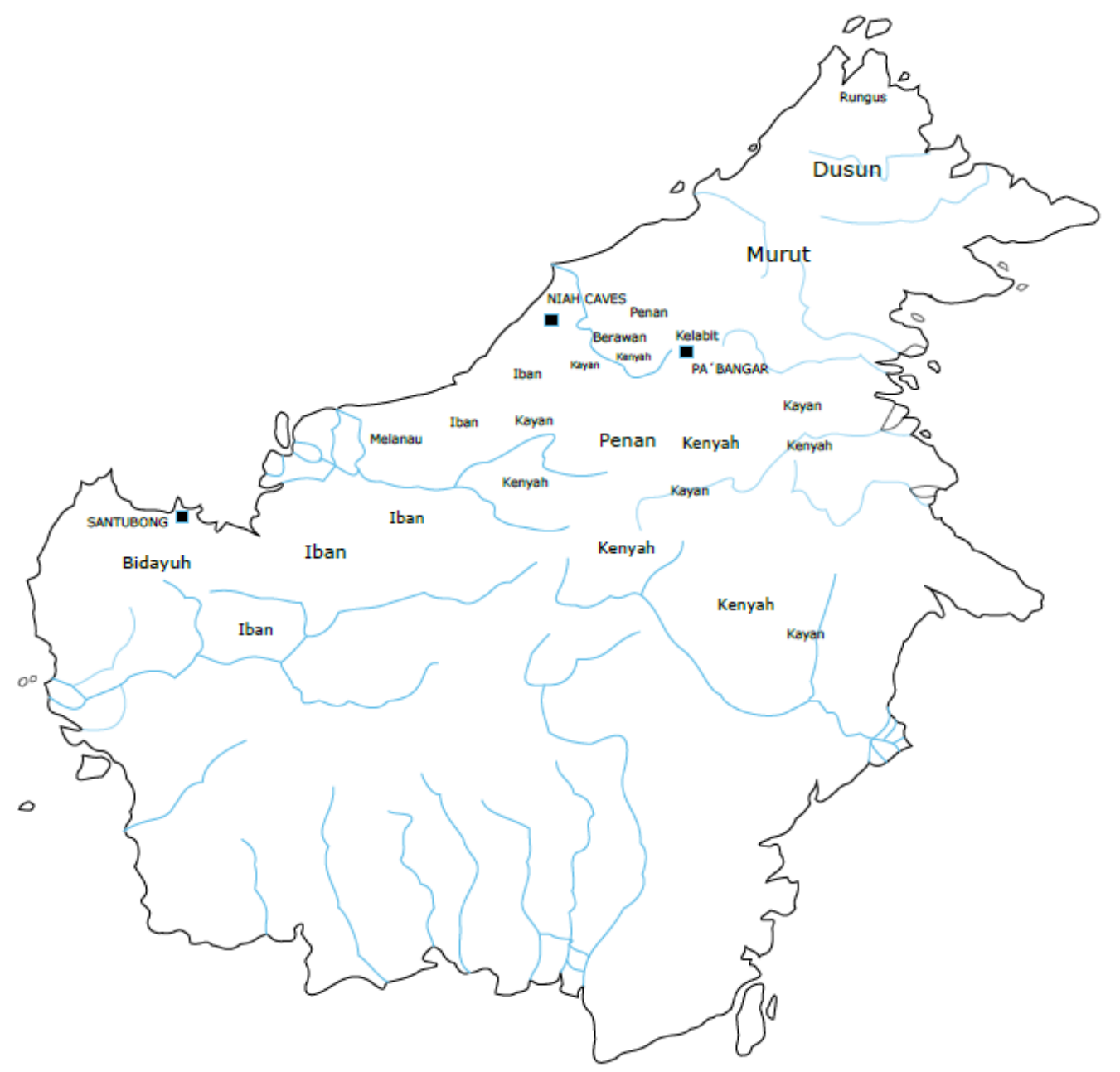

Map of Borneo indicating tribal regions and locations of archaeological sites mentioned in the text. Tribal distributions adapted from Sellato1989.

\section{Bibliography}

Beavitt, P (2006) Melanau sickness images: spirits given physical form. Interfaces 26: 95-102. Google Scholar search

Césard, N (2014) Heirloom and marriage payments: transmission and circulation of prestige jars in Borneo. Indonesia and the Malay World 42(122): 62-87.

Crossref

Chin, L (1980) Cultural Heritage of Sarawak. Kuching: Sarawak Museum. Google Scholar search

Chin, L and Mashman, V (1991) Sarawak Cultural Legacy: A Living tradition.

Kuching: Society Atelier Sarawak. Google Scholar search

Chong, CS (1987) Traditional Melanau wood carving (bilum) in Dalat, Sarawak.

Kuching: Persatuan Kesusasteraan Sarawak. Google Scholar search

Everett, HH and Hewitt J (1909) A history of Santubong, an island off the coast of Sarawak. Journal of the Straits Branch of the Royal Asiatic Society 52:1-33.

Google Scholar search 
Griswold, AB (1962) The Santubong Buddha and its context. Sarawak Museum Journal 10(19-20): 363-371. Google Scholar search

Haji Adam, J, Wilcock, CC, and Swaine, MD (1992) The ecology and distribution of Bornean Nepenthes. Journal of Tropical Forest Science 5(1): 13-25. Google Scholar search

Harrisson, T (1958) Megaliths of central and west Borneo. Sarawak Museum Journal 8(12): 394-401. Google Scholar search

Harrisson, T (1958) A living megalithic in upland Borneo. Sarawak Museum Journal 8(12): 694-702. Google Scholar search

Harrisson, T (1973) Megalithic evidences in east Malaysia. Journal of the Malayan Branch of the Royal Asiatic Society 46(1): 123-149. Google Scholar search

Hung, HC, Iizuka, Y, Bellwood, P, Nguyen, KD, Bellina, B, Silapanth, P, Dizon, E, Santiago, R, Datan, I and Manton, JH (2007) Ancient jades map 3,000 years of prehistoric exchange in Southeast Asia. PNAS 104(50): 19745-19750. Crossref

Iizuka, Y, Bellwood, P, Datan, I and Hung, HC (2005) Mineralogical studies of the Niah West Mouth jade lingling-o. Sarawak Museum Journal 61(82): 19-29. Google Scholar search

Kurui, E and Kaboy, T (1989) Melanau ethno-arts and handicraft. Sarawak Museum Journal 40(61): 251-257. Google Scholar search

Lenjau, M, Sirait, MT and Sellato, B (2012) Rattan and bamboo handicrafts of the Kenyah. In: B Sellato (ed.) Plaited arts from the Borneo rainforest. Honolulu: University of Hawaii Press, 205-223. Google Scholar search

Liew, R (1962) Music and Musical Instruments in Borneo. Journal of the Sabah College Borneo Society 3(10): 10-16. Google Scholar search

Lim, CKN, and Abdul Rahman, MF (2016) Evolution of sape: from longhouse to the international stage. Journal of Borneo-Kalimantan 2(1): 42-52. Google Scholar search

Matusky, P (1986) Aspects of musical style among the Kajang, Kayan and Kenyahbadang of the Upper Rejang River: a preliminary survey. Sarawak Museum Journal 36(57): 185-229. Google Scholar search

Matusky, P (1991) Musical instruments of Sarawak. In: L Chin and V Mashman (eds.) Sarawak Cultural Legacy, a living tradition. Kuching: Society Atelier Sarawak, 217-230. Google Scholar search

Morris, HS (1997) The Oya Melanau: traditional ritual and belief with a catalogue of Belum carving. Sarawak Museum Journal Special Monograph No. 9 52(73): 1-388. Google Scholar search

Revel-Macdonald, N (1988) The Dayak of Borneo: on the ancestors, the dead and the living. In: JP Barbier and D Newton (eds.) Islands and ancestors: indigenous styles of Southeast Asia. New York: MMA and Geneva: Barbier-Mueller Museum, 66-85. Google Scholar search

Sellato, B (1989) Naga dan burung enggang [Hornbill and Dragon]: Kalimantan, Sarawak, Sabah, Brunei. Jakarta: Elf Aquitaine. Google Scholar search

Sellato, B (2016) The Ngorek of the Central Highlands and 'Megalithic' activity in Borneo. In C Jeunesse, P Le Roux and B Boulestin (eds.) Megalithismes vivants et passes: approaches croisees [Living and Past Megalithisms: interwoven approaches]. Oxford: Archaeopress Archaeology, 117-149. Google Scholar search 
Swayne, JC (1933) Rejang baskets from Sarawak. Journal of the Malayan Branch of the Royal Asiatic Society 11(2): 185-189. Google Scholar search

Whittier, HL and Whittier, PR (1988) Baby carriers: a link between social and spiritual values among the Kenyah Dayak of Borneo. Expedition 30 (1): 5158. Google Scholar search

Williams, TR (1961) The form, function, and culture history of a Borneo musical instrument. Oceania 32(3): 178-186. Crossref

Wolley, GC (1932) Murut basketwork. Journal of the Malayan Branch of the Royal Asiatic Society 10: 23-26. Google Scholar search 